\title{
THE NEW PUBLIC LAW MOVEMENT: MODERATION AS A POSTMODERN CULTURAL FORM
}

\author{
William N. Eskridge, Jr. * \\ and Gary Peller**
}

The past twenty years have witnessed an explosion of public law scholarship, as legal scholars reconceptualized themes of administrative law, legislation, and constitutional law; created almost from scratch whole new areas of public law scholarship, including discrimination, environmental, and consumer protection theory; and enlivened discourse with concepts drawn from microeconomics, public choice theory, civic republicanism, practical philosophy, and hermeneutics. This intellectually intense activity has suggested the possibility that public law discourse has entered a "critical stage" 1 and stimulated the Michigan Law Review to hold a conference in October 1990 on whether there is something that might be called "New Public Law." At first we thought there certainly was. We still do, but on further reflection we think that the more interesting inquiry is how these new developments in public law relate to the recent politicization of jurisprudence.

This inquiry was a daunting project for us, in part because the complexity of the historical analysis and our tendency toward abstraction continually threatened to blur the focus of the inquiry, namely, to identify and analyze a "movement" within legal scholarship. Also; we approached the topic from very different perspectives. One of us viewed the New Public Law as an exciting positive development, the other viewed it with skepticism. What we needed was a method for

- Professor of Law, Georgetown University. B.A. 1973, Davidson College; M.A. 1974, Harvard University; J.D. 1978, Yale. - Ed.

** Professor of Law, Georgetown University. B.A. 1977, Emory; J.D. 1980, Harvard University. - Ed.

We are grateful to Alex Aleinikoff, Dan Ernst, Dan Farber, Cynthia Farina, Phil Frickey, Mike Seidman, Joe Singer, Cass Sunstein, and Mark Tushnet for comments on earlier versions of this article, to the participants in the Michigan Law Review's Conference on the New Public Law for their criticism of the earliest version of this article, and to participants in faculty workshops at Boston University Law School and the Georgetown University Law Center for their most constructive sessions with us. Bruce Knivila provided valuable research assistance. Dean Judy Areen and Associate Dean Wendy Williams provided financial support for this project; we thank them for that support and their intellectual encouragement.

1. B. Ackerman, Reconstructing American LAW 24 (1984). 
concretizing the discussion and for presenting its historical complexity and for allowing us to explore our own differences of perspective. Based upon these concerns, we have chosen to focus on two state court cases, one involving nuclear protesters and the other involving a Catholic university's refusal to recognize a gay and lesbian student group. We use these cases as a grounding to present three accounts of twentieth-century American legal thought, each of which illuminates new developments in public law in a different but perhaps complementary way.

The first story is a fairly conventional one, focusing on the continuity of modern legal discourse and the way in which recent public law scholarship carries on the legal process tradition. This account emphasizes the legal process synthesis, which constituted a new center for American law, a center that denied the legal realists' "extreme" charges, even while assimilating the ideological assumptions of the New Deal into a strong and systematic philosophy supportive of the new elite-endorsed status quo in America. By 1958, legal process theory had achieved consensus status in legal academic circles, a consensus that has dominated public law scholarship for the past thirty years. Challenges from law and economics and critical legal studies (CLS) in the 1970s have undermined legal process' intellectual prestige in legal discourse, yet the legal process focus on institutional relationships, the process of lawmaking, and an overriding standard of purposive coherence continues to dominate public law scholarship. Indeed, most of the new developments in public law scholarship - civic republicanism, public choice theory, and law and interpretation - are still usually presented in legal process ways.

If the first story is one of continuity, the second story is one of generational and political rupture. At the same time that elite legal scholars were crafting the legal process materials, oppositionist lawyers, activists, and scholars were challenging the system of racial apartheid through the civil rights movement. The generation of scholars that followed the legal process founders (our generation of babyboomers) was molded by the civil rights movement and by the concomitant critique of the political theory underlying the legal process philosophy. What might truly be called New Public Law has been a rethinking of political assumptions by legal scholars in the 1970s and 1980s. The key intellectual moves include an antipluralism which rejects the idea that political preferences are exogenous to politics; an embrace of the normativity of law, i.e., that law's legitimacy depends upon substantive justice and not procedural correctness; and a practical reasoning which seeks to reconcile colliding community norms 
through dialogue and reconciliation. The New Public Law philosophy is evident across the various public law categories.

Our third version of the development of a New Public Law scholarship describes it as a genre in the particular context of the polarization of academic legal discourse in the 1970s and 1980s. There is nothing inevitable about the continuation and reform of the legal process ideology that we describe in the first two sections. In part, what identifies the New Public Law as a genre of scholarship is a generalized sense of writers making similar choices in a relatively charged ideological setting. As a movement, the New Public Law is unmistakably situated as a "center" between what is perceived as an overly objectivist and conservative law and economics and an overly confrontational and politicizing CLS. In our description, the New Public Law contains two roughly distinct subgroups that echo this external structure: New Public Law scholarship focusing on public choice theory and on the "fit" of social problem and regulatory mechanism is a subdued version of the technocratic tendencies of the law-and-economics right; the emphasis on indeterminacy and the inevitability of choice in a distinctly progressive wing of New Public Law scholarship is likewise an echo of the left's emphasis on the politics of social construction. A great part of the attraction of the movement relates to the fact that it is generally tilted toward the left in terms of its intellectual positions. This intellectual overlap is evident in the proclaimed rejection of "positivist" or "objectivist" epistemology that lends a postmodern feature to a significant amount of New Public Law scholarship even if one would not think of the work as avant garde in any other sense. Like characteristic CLS work, the New Public Law scholarship rejects objectivist imagery about law. Law does not reside in a text, waiting to be pulled out by a subject (formalism), nor is it law simply because the subject declaring it is the duly established institution (legal process). Instead, law is socially constructed, a matter of continuous popular, as well as institutional, interpretation. This powerfully radical idea links the New Public Law to CLS.

\section{The Jurisprudence of Proceduralism and the New Legal Process}

At the center of our first story (the story of continuity) is the legal process synthesis that evolved in the period between 1940 and $1958 .{ }^{2}$

2. We use these dates because they represent the publication dates of two legal process classics: L. FULLER, THE LAW IN QUEST OF ITSELF (1940), which represented mainstream academics' rejection of legal realism and the beginnings of their quest for a unified way of thinking about law, and H. HaRT \& A. SACks, The Legal Process: Basic Problems in the Making 
The legal process position represented a victory over opposing legal ideologies, particularly the common law formalists, who represented a conservatism repudiated by the New Deal, as well as the critical legal realists, who argued that all law is politics and thereby impugned the neutrality and legitimacy of law. Like the realists, for example, the process theorists viewed law as purposive and dynamic, but protected the legitimacy and objectivity of law by focusing on the process and institutions by which law evolved.

Legal process transformed public law discourse, legitimating the modern regulatory state without sacrificing its flexibility in a dynamic world. But from the beginning, legal process theory was beset by a tension between its legitimating methodology (proceduralism and institutional competence) and its goal (dynamic purposive law). That tension generated both liberal and conservative legal process traditions. Over time, external attacks from the right (law and economics) and the left (CLS) exacerbated this internal tension. There emerged in the 1970 s and 1980 s a distinctively progressive movement within the legal process tradition, but also seeking to transform that tradition, by shifting its focus decisively from proceduralism and institutional competence to dynamic purposive law that meets the community's substantive needs. This is a "new" movement, but more a "new legal process" than a watershed in thinking about public law.

We want to tell this story in more detail by reference to the "Case of the Nuclear Protesters," State v. Warshow. ${ }^{3}$ John Warshow and his colleagues traveled to Vernon, Vermont, to.protest against alleged safety risks at the main gate of the Vermont Yankee nuclear power plant and to prevent it from restarting after a shut-down for repairs. After refusing requests by Vermont Yankee and the police to leave the plant, Warshow and his colleagues were arrested for criminal trespass. At trial, they invoked the defense of necessity, which privileges otherwise criminal conduct when the harm or evil sought to be avoided by such conduct is greater than the values protected by the criminal prohibition. They tried to present evidence that there was good reason for them to have believed that the Vermont Yankee plant presented an

AND APPLICATION OF LAW (tent. ed. 1958), which is the classic synthesis of legal process thought. Other well-known legal process works of this period are H. HART \& H. WECHSLER, The Federal CourTS AND THE Federal System (1953); Frankfurter, Some Reflections on the Reading of Statutes, 47 Colum. L. REv. 527 (1947); Fuller, The Case of the Speluncean Explorers, 62 HARV. L. REv. 616 (1949) [hereinafter Fuller, Speluncean Explorers]; Fuller, The Forms and Limits of Adjudication, 92 HARV. L. REv. 353 (1978) (circulated in draft form during 1950s and excerpted in H. HART \& A. SACKS, supra, at 421-26); Fuller, Positivism and Fidelity to Law - A Reply to Professor [H.L.A.] Hart, 71 HARv. L. REv. 630 (1958); Wechsler, Toward Neutral Principles of Constitutional Law, 73 HARv. L. Rev. 1 (1959).

3. 138 Vt. 22, 410 A.2d 1000 (1979). 
imminent danger to the community because of perceived defects that could have led to a meltdown. The trial judge refused to admit that evidence and refused to present Warshow's necessity defense to the jury. After conviction in the jury trial, the defendants appealed to the Vermont Supreme Court, which affirmed the convictions.

\section{A. From Common Law Formalism to Legal Process}

The morphogenesis of serious and sustained American public law scholarship is a complicated story whose contours are only now becoming apparent. ${ }^{4}$ We do not propose to tell that story in any detail here, and will be content to suggest one historic dynamic. To do so, we will show how the historical structure of American public law discourse is evident in the three opinions by the Vermont justices in Warshow. The intellectual elements of this dynamic include an initial baseline of rule-like formalism, reflected by the majority opinion in Warshow; a dramatic attack of that approach through legal realism; and then a resolution, reflected in the concurring and dissenting opinions, through a focus on proceduralism and institutional decisionmaking boundaries.

We start with common law formalism, the ideology accepted by elite legal society in the 1890s and in ensuing decades. ${ }^{5}$ It accepted the primacy of the "private" sphere over the "public" sphere - "private" property was the starting point, and consented-to arrangements (contracts, wills, marriages, leases) were the modes of change. Unless the

4. An excellent discussion of the intellectual background of legal process is E. PuRCeLI, The Crisis of Democratic Theory: Scientific Naturalism \& THE Problem of Value (1973). Our account in this Part draws heavily upon this source and upon Deutsch, Neutrality, Legitimacy, and the Supreme Court: Some Intersections Between Laws and Political Science, 20 STAN. L. Rev. 169 (1968); Eskridge, Metaprocedure (Book Review), 98 YALE L.J. 945 (1989); Mensch, The History of Mainstream Legal Thought, in The Polrtics of LAw: A Progressive CritiQue 13 (D. Kairys rev. ed. 1990); Peller, Neutral Principles in the 1950's, 21 U. Mich. J.L. REF. 561 (1988); Vetter, Postwar Legal Scholarship on Judicial Decision Making, 33 J. LEGAL Evuc. 412 (1983); White, From Realism to Critical Legal Studies: A Truncated Intellectual History, 40 Sw. L.J. 819 (1986).

5. We consider common law formalism to be something more than the traditional understanding of formalism as simply a closed system of rules scientifically derived from reported cases (such as Euclidean geometry). See Casebeer, Teaching an Old Dog New Tricks: Coppage v. Kansas and At-Will Employment Revisited, 6 CARDozo L. Rev. 765 (1985); Kennedy, Form and Substance in Private Law Adjudication, 89 HARv. L. Rev. 1685 (1976); Kennedy, Toward a Historical Understanding of Legal Consciousness: The Case of Classical Legal Thought in America, 1850-1940, 3 RES. L. \& Soc. (1980); Fineman \& Gabel, Contract Law as Ideology, in The Politics of LAw, supra note 4, at 373; Gordon, Legal Thought and Practice in the Age of American Enterprise, 1870-1920, in Professions and Professional IdeOlogies IN AMERICA (G. Geison ed. 1983); Peller, The Metaphysics of American Law, 73 CALIf. L. REv. 1151 (1985); Singer, Legal Realism Now (Book Review), 76 CALIF. L. REv. 465 (1988). Instead, our focus is on the underlying ideology, for which formalism was mainly the vocabulary of expression. For useful but different treatments of the topic, see G. GILMORE, THE AGES OF AMERICAN LAW (1977); Grey, Langdell's Orthodoxy, 45 U. PITT. L. REv. 1 (1983). 
private actor did something irresponsible (nuisance, negligence, breach of consented-to arrangement, criminal behavior), the common law left her alone. Similarly, it went without saying for common law formalists that the primacy of the private sphere was fair and good, in part because private interactions were fair means for allocating resources. Indeed, one role of law was to assure the integrity of these market mechanisms, by enforcing consented-to arrangements and nullifying efforts to interfere with such arrangements by labor unions, trusts, and governments. Finally, common law formalists believed that law is a neutral concomitant to the private market, and that law's own coercion is necessary to maintain the ultimate freedom of American citizens. Under this ideology there was little interest in government regulation, except as a "policing" mechanism to rectify exceptional market problems. ${ }^{6}$

One "exceptional" problem is disruption of private property rights, and common law formalists policed that with a vengeance. The majority opinion in Warshow is a strong signal that the state will protect property rights against trouble, and the opinion's reasoning follows the rigid, rule-like deductivism associated with formalism. An unspoken premise of the opinion is the need to enforce trespass law stringently. It categorically enumerates the "fundamental requirements" of the necessity defense, but with the warning that "if the qualifications for the defense of necessity are not closely delineated, the definition of criminal activity becomes uncertain and even whimsical."7 One of the requirements, said the court, is that the danger sought to be avoided be imminent. The court found that "low-level radiation and nuclear waste are not the types of imminent danger classified as an emergency sufficient to justify criminal activity," because the court inferred from the record that there was only a "possibility" of a nuclear disaster, and a possibility of statewide devastation is not enough. ${ }^{8}$

The formalist self-image, that of a logic-driven structure of rules protecting the status quo and settled property rights, is nicely reflected in Warshow, but so is the realist counterattack of the 1920s and 1930s. The realists rejected the bias toward the status quo and established interests that they saw in common law formalism. They saw the com-

6. See generally Frug, The Ideology of Bureaucracy in American Law, 97 HARV. L. REV. 1276 (1984); Rabin, Federal Regulation in Historical Perspective, 38 STAN. L. REV. 1189 (1986). The best then contemporary expression of this sort of ideology was E. FREUND, CASES ON ADMINISTRATIVE LAW (1911).

7. State v. Warshow, 138 Vt. 22, 24, 410 A.2d 1000, 1001 (1979).

8. $138 \mathrm{Vt}$. at $25,410 \mathrm{~A} .2 \mathrm{~d}$ at 1002 . According to the court: "To be imminent, a danger must be, or must reasonably appear to be, threatening to occur immediately, near at hand, and impending." $138 \mathrm{Vt}$. at $25,410 \mathrm{~A} .2 \mathrm{~d}$ at 1002 . 
mon law, not as a set of neutral rules, but as a set of policy-driven results, often failing to reflect the genuine needs of the community. Pursuing their critical agenda, the realists developed analytically powerful arguments that could be used to debunk the claims of formalists and expose the ultimate policy grounds of their ostensibly rule-driven decisions.

Given the overlap between the criminal law and tort defense of necessity, it is easy to imagine a realist critique of the Warshow majority. The formal definition of the "imminence" requirement - that the danger sought to be avoided by the nuclear power protestors was "certain" rather than merely "possible" - was too narrow to carry out the full purposes of the necessity defense to subcategorize the criminal law to particular factual contexts. As the realist-inspired Learned Hand calculus for negligence suggested, a low probability of a grave harm was equivalent to a high probability of a minor harm. If a violation of trespass rules is to be privileged when a certain harm of small magnitude is involved - say the loss of the boat in Vincent v. Lake Erie then certainly it should also be privileged when there is a correspondingly lower probability of pyramidically greater harm. In the context of Warshow, the greater harm was perhaps the kind of nuclear disaster that the world has since witnessed at Chernobyl. And in any event, the majority's invocation of "certainty" as a bright-line and categorical inquiry reflected a premodernist world view. The line from a low possibility to a certainty was quantitative, not qualitative; "certainty" just referred to an extremely high probability of an event occurring. After all, even in the exemplar boat-docking cases from tort law upon which the majority relies, the harm to be avoided was the loss of boats at sea in a storm; to believe that beforehand one could know this result with certainty places more faith in the technology of weather and casualty prediction than most in the field profess. The language of weather forecasting and insurance is the language of probability.

And, a realist might argue, the majority's invocation of a categorical failure to show certainty in the offer of proof not only obscures an implicit policy balance that discounts the weight of the danger to be avoided; it also exaggerates the weight of the social interest in the trespass laws that the criminal prohibition protects. As the majority applied the necessity defense, the weight of the public interest in the enforcement of criminal trespass laws was the same regardless of the context of the "violation." Trespass laws protect private property; the nuclear plant is not public property; therefore, the social interest in the protection of the security of private property applied. But one could object that this approach tends to treat all private property alike, re- 
gardless of its social context. There is, at least arguably, a different public interest in protecting private, intimate space (for example, the living room of one's house), than in protecting the sanctity of the grounds of the corporate complexes of huge economic enterprises (for example, the Vermont Yankee nuclear plant). On a continuum from private to public, the grounds of a nuclear power plant fall well beyond the core of private security invoked in the image of private property and seem closer to the quasi-public nature of much of our social space. There was, accordingly, some reason to discount the private property interest in Warshow. Of course, this could be argued in the opposite direction. Given the sensitive and potentially devastating nature of nuclear power mishaps, there is an even greater public interest in strictly enforcing trespass laws in this context: allowing control of operations to be dictated by activist disruption could be more devastating to the societal interest in security than the core image of an invasion of an individual home implies.

The realist point of the foregoing analysis is that the weight of the social interest in private property in the context of the movement to prevent the start-up of the Vermont Yankee nuclear power plant is debatable, and contingent upon a web of social, economic, and legal contexts. It is socially constructed - it cannot be determined by the simple invocation of the formal idea of the protection of private property, since the degree to which "private property" necessarily means strict trespass enforcement will be the consequence of the judicial determination, not its ground. There is no steady baseline dividing public and private interests, contrary to the Warshow majority's formalist rhetoric. Choosing the appropriate weight to give "private property" in this particular case ultimately depended, not upon formally recognizing where the case fit in a predetermined category, but instead upon making a political and social choice. That in turn depended heavily upon whether the judges believed that the power company and the Nuclear Regulatory Commission, and not the protesters, were the socially responsible actors in this setting. One would either create a privilege on the part of the power company that could have disastrous consequences if the company is acting irresponsibly or create a privilege for potentially dangerous citizen groups to disrupt nuclear power production.

One possible implication of this kind of realist analysis was a thoroughgoing positivism: if law is the implicit balancing of social values with nothing objective to guide the procedure, it has no independent normative status; the lawmaking by courts just represents a fact about the world, to be observed, studied, and predicted. Yet another 
version the positivist reaction took was to attempt to ground legitimate lawmaking in the "facts" of social life, to view the policymaking implicit in the realist description as basically functional and technical rather than political and ideological. Two of the five justices rejected the formalist reasoning in Warshow, implicitly adopting realist arguments. Dissenting, Justice Billings argued that Warshow's proffer of evidence fully met the formal standards of the necessity defense, that the court majority was in reality deciding that Warshow's evidence was simply not credible, and that prior Vermont precedents had in similar circumstances required that the jury and not the judge decide such issues of credibility. 9 Both he and concurring Justice Hill believed the issue in the case was really one of policy: "The defense of necessity proceeds from the appreciation that, as a matter of public policy, there are circumstances where the value protected by the law is eclipsed by a superseding value, and that it would be inappropriate and unjust to apply the usual criminal rule."10

Justices Billings and Hill disagreed about the proper policy balance, and this was a central problem of realism. Their demonstration that legal rules do not control common law outcomes, coupled with their emphasis on policy balancing, suggested that the personal values of the decisionmakers (unelected judges) will be decisive, at least much of the time. This, in turn, created a practical distinction between the "is" and the "ought" that had been elided in common law formalism: The most that law can teach us, the realists said, is a description of how decisionmakers do behave; traditional legal study has little or no utility in teaching us how they ought to behave. The more skeptical realists left the impression that judge-made law is neither objective nor neutral. Given the indeterminacy of the issues in a case like Warshow, the court's result has no legitimacy beyond the preference of four upper-middle class white males for the moneyed status quo (the nuclear plant).

Justices Billings and Hill exemplify a postrealist generation that rejected the most positivist dimensions of realism; while they conceded that the substantive issue of whether to privilege the protestors' trespass was inevitably a policy decision, they took as the critical focus of the case whether the balancing of values was already done democratically, through the federal and state structure of licensing and other forms of regulation applied to nuclear power. Rather than engage in the substantive debate over the safety of the Vermont Yankee plant,

9. 138 Vt. at 29-32, 410 A.2d at 1004-06 (Billings, J., dissenting).

10. $138 \mathrm{Vt}$. at $27,410 \mathrm{~A} .2 \mathrm{~d}$ at 1003 (Hill, J., concurring); see $138 \mathrm{Vt}$. at 32, $410 \mathrm{~A} .2 \mathrm{~d}$ at 1006 (Billings, J., dissenting). 
Justices Billings and Hill focused on the jurisdictional and procedural issues regarding whether to defer to other decisionmaking procedures.

Many legal academics who in the 1930s agreed with the realists' rejection of common law formalism vigorously objected to the realists' delinking law from morality (the "is" from the "ought"). ${ }^{11}$ Political theorists in the 1940s suggested a resolution to this debate: for the same reasons that moral philosophy has rejected closed deductive systems with demonstrably right answers (formalism, natural law) in favor of a relativistic view of knowledge and morality that prefers practical to theoretical solutions (functionalism, relativism), so political philosophy should reject totalitarian, absolute values (fascism and communism) in favor of diversity of values and pluralism (democracy). ${ }^{12}$ This move in political philosophy suggested that one reason democracy is superior to fascism is that it rests upon epistemologically sounder premises - its very openness to change enables it to perform better over time. Such a "relativist theory of democracy"13 had important implications for legal philosophy. This new conception facilitated the reconnection of law and morality, but in a less controversial way than common law formalism or natural law theories tried to do. The morality of law lay not in fundamental agreement about substantive principles, but instead in the open structures and procedures of government, the process by which we can govern ourselves notwithstanding disagreements. ${ }^{14}$ This intellectual culture provided the con-

11. The realists' theories threatened law's legitimacy at a time when American intellectuals were frightened by the specter of fascism in Europe and needed reassurance that our democratic system embodied a "rule of law" missing in Nazi Germany. In 1940, two addresses by influential academics argued that realism was subversive of democracy, and that its ethical relativism (whatever is ordered by state decisionmakers is "law") paralleled that of Nazi Germany. See L. Fuller, supra note 2; R. Pound, ConTEMPORARY JuRISTIC TheORY (1940). Note that Pound's own early work, see, e.g., Pound, Spurious Interpretation, 7 ColuM. L. REV. 379 (1907); Pound, Common Law and Legislation, 21 HARv. L. REv. 383 (1908), was highly critical of common law formalism, and that Fuller's first big article, Fuller \& Perdue, The Reliance Interest in Contract Damages (pts. 1 \& 2), 46 YALE L.J. 52, 373 (1936-1937), was an exemplar piece of realist-inspired analysis. See generally E. PURCELl, supra note 4, at 117-58.

12. See J. Dewey, Freedom and Culture (1939); C. Friedrich, The New Belief in the Common Man (1942); E. Herring, The Politics of Democracy: American Parties IN ACTION (1940).

13. E. PURCELL, supra note 4, at 197-217, discusses the movement in American political theory "Toward a Relativist Theory of Democracy" in the 1940s and traces the ways in which such a theory was the basis for a conservative restructuring of American political thought in the 1950s. Id. at 233-72.

14. "[M]ay it not be that modern constitutional democracy is the endeavour precisely to organize government in such a way that disagreement on fundamentals need not be secured?" Friedrich, Democracy and Dissent, 10 POL. Q. 571, 573 (1939); see C. FRIEDRICH, supra note 12, at 181 ("what binds a free people together is not an agreement on fundamentals, but a common way of acting in spite of agreement on fundamentals"); E. HERRING, supra note 12, at 26 ("significant thing is that the ideology of democracy permits the peaceful resolution of interest conflicts through accepted institutions"). 
text for the legal process ideology, underlying the concurring and dissenting opinions in Warshow.

The particular intellectual strategy chosen by the legal process thinkers was a brilliant synthetic rethinking of American public law. ${ }^{15}$ Table 1 crudely summarizes some of the moves made by legal process theory in relation to common law formalism and legal realism. We now examine the essential legal process concepts, namely, the purposive nature of law, the importance of interconnected institutions, and the legitimating role of process. We shall take as our text the Legal Process materials developed by Henry M. Hart, Jr. and Albert Sacks, ${ }^{16}$ and apply it to the issues posed by our Case of the Nuclear Protesters.

\section{TABLE 1}

Common Law Formalism (1890s-1910s)

Primacy of Private Domain over Public (Liberalism)

Common Law Baselines as Starting Points for Analysis

Rules \& Categories Critical to Analysis (Formalism)

\begin{tabular}{l}
\multicolumn{1}{c}{$\begin{array}{c}\text { Legal Realism } \\
\text { (1920s-1930s) }\end{array}$} \\
\hline Primacy of Public over \\
Private (Utilitarianism)
\end{tabular}

Legal Process (1940s-1950s)

Interaction of Public \& Private (Purposivism)

Governmental Regulation as Starting Point; Institutional Competence

Process Critical (Proceduralism)

\section{Law as Purposive}

The concurring and dissenting opinions in Warshow both emphasized the policy purpose of the common law necessity exception. ${ }^{17}$ This was a primary focus of Hart and Sacks, whose legal process materials grounded law's purposivism in a theory of society. "The starting point of the response which human beings seem invariably to make to the basic conditions of human existence is to recognize the fact of their interdependence with other human beings and the community of interest which grows out of it," posited Hart and Sacks. "So recognizing, people form themselves into groups for the protec-

15. Our discussion of the historical situatedness of legal process theory draws upon Eskridge \& Frickey, Legislation Scholarship and Pedagogy in the Post-Legal Process Era, 48 U. PITT. L. REv. 691 (1987); Peller, supra note 4; Weisberg, The Calabresian Judicial Artist: Statutes and the New Legal Process, 35 STAN. L. Rev. 213 (1983); Wellman, Dworkin and the Legal Process Tradition: The Legacy of Hart \& Sacks, 29 ARIZ. L. REV. 413 (1987).

16. H. HART \& A. SACKs, supra note 2.

17. See supra note 10 and accompanying text. 
tion and advancement of their common interests . ..."18 The state is the "over-riding, general purpose group" created "to protect and further the over-riding, basic interests which the members of a community have in common." 19 Given this role of the state, Hart and Sacks took a purposive view of law. Rejecting both the stingy view of law held by common law formalism and the cynical positivism of the legal realists, legal process viewed law as interconnected with society's collective goals: "Law is a doing of something, a purposive activity, a continuous striving to solve the basic problems of social living."20

Hart and Sacks emphasized the role of statutes in modern public law, but of course viewed them as "purposive act[s]."21 For legal process, moreover, enactment of a statute was merely the beginning, and not the end, of lawmaking. ${ }^{22}$ In the modern regulatory state, statutes are not just directives to citizens, but are directives to governmental officials charged with implementing the statutory scheme. Courts and agencies implement statutes through a process of "reasoned elaboration."23 Because "every statute and every doctrine of unwritten law developed by the decisional process has some kind of purpose or objective," the statute or doctrine can be applied to specific problems or controversies by a rational process in which the decisionmaker first identifies the purpose of the statute or doctrine and the "policy or principle" it embodies and then reasons toward the result most consis-

18. H. HART \& A. SAcks, supra note 2, at 2.

19. Id. Note how this story differs from the traditional liberal story of the state as a social contract among atomistic individuals seeking to avoid the brutish state of nature: the legal process story emphasizes human beings' interrelatedness rather than their separateness and the positive social benefits of cooperation rather than the simple need to resolve conflicts peacefully. See id. at 1 (emphasizing how "people are continuously and inescapably dependent upon one another" and their need for "knowledgeable cooperation").

20. Id. at 166. "Whatever particular objects may be sought by the various branches of our law, it is apparent on reflection that all of them are directed toward facilitating and improving men's coexistence and regulating with faimess and equity the relations of their life in common." Fuller, Speluncean Explorers, supra note 2, at 621. The discussion of purposiveness is part of Hart and Sacks' broader discussion of law as a "science of society," which they contrasted to the objectivity possible in the science of nature. H. HART \& A. SACKS, supra note 2, at 116-23.

21. H. HART \& A. SACKs, supra note 2, at 1156 ("The idea of a statute without an intelligible purpose is foreign to the idea of law and inadmissible.").

22. The "law" of a statute is not complete when the legislative stamp has been put upon it; subsequent judicial decisions add meaning and effect to the statutory direction. The interpretation of a statute with respect to wholly unforeseen issues requires the exercise of originative thinking on the part of those charged with its application to particular controversies, whether these be judges or administrative officers.

Jones, Extrinsic Aids in the Federal Courts, 25 IowA L. REv. 737, 761 (1940) (footnotes omitted).

23. H. HART \& A. SACKs, supra note 2, at 162-68 ("The Process of Reasoned Elaboration of Purportedly Determinate Directions") (emphasis omitted); id. at 168-71 ("The Reasoned Elaboration of Avowedly Indeterminate Directions") (emphasis omitted). 
tent with that policy or principle. ${ }^{24}$ If the underlying policy appears ambiguous, "the official should interpret it in the way which best harmonizes with more basic principles and policies of law."25 This is precisely what Justices Billings and Hill saw themselves doing - crafting the contours of necessity defense doctrine by reference to its overriding utilitarian purpose, and society's overall goal of self-preservation.

\section{Law as an Interconnected Institutional System (Institutional Competence)}

As a purposive system, law includes a number of "substantive understandings or arrangements" to govern the conduct of those living in the community. ${ }^{26}$ Yet Hart and Sacks emphasized the greater importance of the "constitutive or procedural understandings or arrangements" by which the substantive arrangements are applied, interpreted, and changed. ${ }^{27}$ "These institutionalized procedures . . . are obviously more fundamental than the substantive arrangements in the structure of a society, if not in the realization of its ultimate aims, since they are at once the source of the substantive arrangements and the indispensable means of making them work effectively."28

If law is the channeling of the private sector to optimize productive collaboration in society, the question becomes how to tackle the complex issues of a diverse and dynamic society. ${ }^{29}$ Drawing upon a central tenet of the relativist theory of democracy, Hart and Sacks

24. Id. at 166-67; see id. at 1179-203 (Hart \& Sacks' purposive theory of statutory interpretation); Weisberg, supra note 15 , at 233-36.

25. H. HART \& A. SACKs, supra note 2, at 165 . The rationale underlying this suggestion is laid out in id. at 165-68. Note here the importance of policies and principles for legal process theory. As the state over time addresses social problems of cooperation and conflict, certain policies and principles become clear because of their practical importance in dealing with the issues. For legal process, law "rests upon a body of hard-won and deeply-embedded principles and policies." Id. at 101. The existence of underlying policies and principles gives law a seamless as well as dynamic quality. For agencies administering a vague statutory scheme, the underlying principles and policies provide direction for initial applications of the statute to specific problems, and then those applications together with the principles and policies narrow the range of agency discretion in future cases. For courts interpreting ambiguous statutes or precedents, their underlying principles and policies provide the necessary context to reach a reasoned decision, consistent with the broad canvass of law. Principles and policies form the basis for extending a rule or statute to a novel context, $i d$ at $386-406$, reformulating old rules or provisions, id. at 407-26, and even replacing prior rules or practices with new ones. Id. at 565-89.

26. Id. at 3 (emphasis omitted).

27. Id. (emphasis omitted).

28. Id. "An organized society is one which has an interconnected system of procedures adequate, or claiming to be adequate, to deal with every kind of question affecting the group's internal relations, and every kind of question affecting its external relations which the group can establish competence to deal with." Id. at 4.

29. Id. at 180-83 (quoting Hart, The Relations Between State and Federal Law, 54 Colum. L. REV. $489-91$ (1954)). 
endorsed the idea that broad dispersion of problem-solving is the most practical way to proceed. Because of the "boundless and unpredictable variety" of our dynamic society, legal process asserted that "private ordering is the primary process of social adjustment."30 To the extent that private ordering does not solve the collective action problem, as in the case of nuclear energy, Hart and Sacks contemplated an interaction between private and public activity on the issue. The public activity, in turn, tends to be somewhat dispersed and contemplates interaction between different institutions based upon their relative "competence" to handle the problem. Thus, the debate between Justices Hill (concurring in the court's affirmance of the trespass conviction) and Billings (dissenting) in Warshow was essentially over the competence of a common law court to set nuclear regulatory standards that might be different from those set by the Congress, the Vermont legislature, and the federal and state regulators. ${ }^{31}$

Justices Hill and Billings were following, to the letter, the Hart and Sacks approach to the common law. ${ }^{32}$ Although Hart and Sacks accepted the conventional view of the common law as the "initial resort" for problems that cannot be solved by private activity, their treatment was concerned "as much with the shortcomings of the common law as a form of law as with its merits" and sought "to lay a foundation for an understanding of the frequent need for one of the more sophisticated types of administered regulation or non-regulatory control." 33 More specifically, a recurring theme of legal process theory is whether a problem of collective action is better left to legislative, administrative, or private solution. Thus, the Warshow concurring opinion by Justice Hill argued that the common law defense of necessity "does not deal with non-imminent or debatable harms, nor does it deal with activities that the legislative branch has expressly sanctioned and found not to be harms." 34 Justice Hill felt that the state and federal legislative approval of nuclear power generally had foreclosed judicial

30. Id. at 183. Unlike the common law formalists, Hart and Sacks were not attempting to elevate the private sphere over the public sphere, as a normative matter. Instead, Hart and Sacks take the private sphere as a starting point for the functional reason that the number and variety of disputes in society can best be handled by initial resort to private resolution. See Peller, supra note 4, at 591-99.

31. Compare Warshow, 138 Vt. at 26-29, 410 A.2d at 1003 (Hill, J., concurring) with Warshow, $138 \mathrm{Vt}$. at 32-33, $410 \mathrm{~A} .2 \mathrm{~d}$ at 1006 (Billings, J., dissenting).

32. See generally H. HART \& A. SAcks, supra note 2, ch. 3 ("The Courts as Places of Initial Resort for Solving Problems Which Fail of Private Solution").

33. Id. at 366.

34. Warshow, $138 \mathrm{Vt}$. at 27, 410 A.2d at 1003 (Hill, J., concurring). Modern codifications of the necessity defense typically contain a provision carving out an exception to the necessity defense where the legislature has plainly rejected the cost-benefit analysis put forward by the defendant. E.g., MODEL PeNAL CoDE § 3.02(1)(c) (tent. ed. 1958). 
redetermination of the public danger issue. Justice Billings, in dissent, agreed that it would be inappropriate to privilege conduct if the legislature had decided that the Vermont Yankee plant was safe, but sharply disputed that generalized legislative determinations of nuclear safety should reach situations in which the protesters asserted particularized reasons to believe that a nuclear plant had specific safety defects. ${ }^{35}$

\section{The Importance of Process (Proceduralism)}

Procedure was critically important to the legal process vision. Again, this emphasis parallels attitudes held by defenders of the relativist theory of democracy. In a government of dispersed power and diverse views about substantive issues, "the substance of decision cannot be planned in advance in the form of rules and standards," but "the procedure of decision commonly can be." 36 Procedure is practically important in the Hart and Sacks materials for three reasons. First, procedure is an effective way to obtain good decisions. ${ }^{37}$ The procedures that ensure good legislative decisions, for example, are those suggested by the relativist theory of democracy - openness to the views of all affected persons and groups, focus on factual information subjected to expert and critical scrutiny, and public deliberation through which the pros and cons are thoroughly discussed. ${ }^{38}$ Second, procedure is the means by which the interconnected institutional system works together effectively. Procedure not only defines the relative roles and duties of the different institutions (described above), but also provides mechanisms for systemic self-correction, an important virtue under the relativist theory of democracy. ${ }^{39}$

35. $138 \mathrm{Vt}$. at $32,410 \mathrm{~A} .2 \mathrm{~d}$ at 1006 (Billings, J., dissenting).

36. H. HART \& A. SACKS, supra note 2, at 173.

37. Hart and Sacks reasoned: "Experience is replete with proof of the vitally important relation between procedure and substance. A procedure which is soundly adapted to the type of power to be exercised is conducive to well-informed and wise decisions. An unsound procedure invites ill-informed and unwise ones." $I d$.

38. Id. at 715-16 ("general agreement" that legislative process should be "informed," "deliberative," and "efficient"). The suggestion that "the best criterion of sound legislation is the test of whether it is the product of a sound process of enactment" epitomizes the legal process philosophy. Id. at 715. The quotation in text is a rhetorical question in Hart and Sacks, to which they reply: "All will probably agree that procedure is a relevant consideration. There is less agreement about the elements of a sound process." And then Hart and Sacks proceed to report "general agreement" that legislation should be informed, deliberative, and efficient. Id. at 715-16.

39. "Procedural safeguards, appropriately adapted, operate alike in the control of powers of reasoned elaboration, on the one hand, and of powers of continuing discretion, on the other." Id. at 173. For the administrative process, such safeguards include "the arrangements which prescribe the procedure to be followed in exercising ... power: the information which must be secured; the people whose views must be listened to; the findings and justification of the decision which must be made; and the formal requisites of action which must be observed." Id. For the legislative process, the safeguards include the constitutional requirements of bicameralism and 
Third, and most intimately related to the relativist theory of democracy, procedure is critical to law's legitimacy. One may debate the correctness of a legal decision or its popular support, but legal process posited that if the decision is the result of established procedures, that alone lends it some degree of legitimacy. Consider Hart and Sacks' famed "principle of institutional settlement."

Implicit in every such system of procedures is the central idea of law - an idea which can be described as the principle of institutional settlement.... The alternative to disintegrating resort to violence is the establishment of regularized and peaceable methods of decision. The principle of institutional settlement expresses the judgment that decisions which are the duly arrived at result of duly established procedures [for making decisions] of this kind ought to be accepted as binding upon the whole society unless and until they are duly changed.

....

... When the principle of institutional settlement is plainly applicable, we say that the law "is" thus and so, and brush aside further discussion of what quote "ought" to be. Yet the "is" is not really an "is" but a special kind of "ought" - a statement that, for the reasons just reviewed, a decision which is the duly arrived at result of a duly established procedure for making decisions of that kind "ought" to be accepted as binding upon the whole society unless and until it has been duly changed. 40

Compare the Hart and Sacks principle with this key passage from the Warshow concurring opinion:

Implicit within these statutory enactments is the policy choice that the benefits of nuclear energy outweigh its dangers.

If we were to allow defendants to present the necessity defense in this case we would, in effect, be allowing a jury to redetermine questions of policy already decided by the legislative branches of the federal and state governments. This is not how our system of government was meant to operate. ${ }^{41}$

The principle of institutional settlement expressed in Hart and Sacks, and parrotted in Justice Hill's concurrence, provides a summarizing concept for the legal process philosophy. Legal process thinkers (Hart and Sacks) and judges (Justice Hill) could avoid taking positions on "questions of policy" and yet avoid sounding like mindless positivists. The principle of institutional settlement permitted judges and scholars to discuss law in normative terms - such-andsuch a policy "should" be followed, because it has been "arrived at as

presentment, as well as the rules and safeguards adopted voluntarily by Congress, and the "ultimate check" of the ballot box. Id. at 172-73, 178-79. For the judicial process, the safeguards include the due process guarantees of notice, a meaningful right to be heard by an impartial decisionmaker, and the right to appellate review.

40. Id. at 4-5 (emphasis in original).

41. State v. Warshow, 138 Vt. 22, 28, 410 A.2d 1000, 1003 (1979) (Hill, J., concurring). 
a result of duly established procedures." The normativity of law rests in its process, and not in its substance. As we shall now see, however, legal process' proceduralism was itself subject to different ideological interpretations, and almost immediately in history dissolved into competing normative visions.

\section{B. The Ambiguous Legacy of Legal Process Theory and Attacks from Left and Right}

The legal process synthesis was a brilliant achievement, for it transcended the realist/formalist debate in a way that fit well with the relativist theory of democracy. The scholars were able to marginalize Lochner-style constitutional law as impermissible value-imposition by unelected judges, while simultaneously moving mainstream American jurisprudence into the modern era by acknowledging and legitimating the inescapably political character of the common law, statutory interpretation, and administrative law. In short, legal process asserted the illegitimacy of activist judicial review while asserting activism in virtually all other institutional settings. You could get rid of Lochner but still have McPherson v. Buick and the Federal Trade Commission.

That achievement also bespoke an ambiguous legacy of legal process theory, an ambiguity that became clear in the 1960s and 1970s in cases such as Warshow. On the one hand, the proceduralism and institutional competence themes of legal process theory were potentially quite conservative. For example, the principle of institutional settlement is not only the apotheosis of legal process' proceduralism, but also of its status quo orientation. It reintegrated law and morality in a way that privileges the status quo, since the fairness or justice of existing rules and arrangements requires no continuing defense under the legal process philosophy. ${ }^{42}$ Once the "duly established" mechanisms of government have spoken on a legal issue, its resolution is the normatively "right" answer until that resolution is altered through the duly established (statist) procedures. Mainstream process theory, represented by such eminent scholars as Alexander Bickel, Paul Bator, Harry Wellington, and Robert Bork, assiduously developed these formalist, conservative themes in constitutional law and federal jurisdiction after the 1950s.

Justice Hill's concurring opinion in Warshow emphasizes the conservative, status quo features of legal process theory. While recognizing that the necessity defense implicated important public policy concerns, he avoided any opinion on the merits by deferring to the

42. See Peller, supra note 5. 
"deliberate legislative choice as to the values at issue."43 By establishing administrative "mechanisms for the regulation of nuclear power," Justice Hill reasoned that the legislature had implicitly determined that the benefits of nuclear power always outweigh the costs. 44 "I express no opinion as to the relative merits or demerits of nuclear energy, nor do I question the sincerity of defendants' beliefs. All that I would hold is that this Court is not the proper forum to grant defendants the relief they seek." 45

On the other hand, emphasis on institutional competence and proceduralism, if carried too far, might undermine the very idea that leads off the Hart and Sacks materials - the purposiveness of law as a way to facilitate our social interdependence. Thus a rigid adherence to procedures and deference to institutional competence were not defensible, even under the legal process philosophy, if the procedures were faulty and the institutions not as competent as we might have thought. It would be mere formalism of an institutional variety if one deferred to a decision of the Nuclear Regulatory Commission in a case like Warshow just because the decision emanated from that agency; if the purpose of creating the agency was to preserve the reasonable safery of the public, that agency's entitlement to deference depends on the assumption that its decisions reflect this public policy - the very issue the protestors contest. Substantive and procedural issues were indistinguishable since one way we might recognize faulty procedures and incompetent institutions is by their tendency to produce dumb results. Although legal process theory in the 1950s had developed in part to avoid lawtalk about substantive results, progressive process scholars in the 1970s, such as Charles Black, Owen Fiss, John Hart Ely, and Frank Michelman, found it impossible to remain true to legal process' purposivism without keeping one eye on substance.

In this vein, the concurrence and dissent reflect the alternatives of a formalist or purposive identification of institutional legitimacy from within the legal process analytic. Justice Hill was willing to defer to a "democratic" decision based simply on the fact of legislative delegation of safety to regulatory agencies, but Justice Billings' dissenting

43. Warshow, $138 \mathrm{Vt}$. at 27, 410 A.2d at 1003 (Hill, J., concurring).

44. $138 \mathrm{Vt}$. at $27,410 \mathrm{~A} .2 \mathrm{~d}$ at 1003 . Justice Hill chided Justice Billings for questioning the efficacy of the statutory scheme:

The legislative framework was set up to deal with the very situation defendants offered to prove "might" happen. But because neither the state legislature nor Congress acted to shut down the power plant based upon speculative possibilities does not, in my opinion, give rise to the questionable inference that there was an emergency which the regulatory scheme failed to avert.

$138 \mathrm{Vt}$. at $28,410 \mathrm{~A} .2 \mathrm{~d}$ at 1004 .

45. $138 \mathrm{Vt}$. at $28,410 \mathrm{~A} .2 \mathrm{~d}$ at 1003 . 
opinion in Warshow rejected the concurrence's effort "to hide behind inferences that the legislature precluded the courts from hearing the defense of necessity in the instant case." 46 For one thing, Justice Billings questioned the appropriateness of deference to a legislative judgment "where, as here, the defendants offer to prove an emergency which the regulatory scheme failed to avert." 47 For another thing, he disputed Justice Hill's "implication" that the legislature intended to halt common law development when it adopted the statutory scheme. Citing general statutory admonitions to develop popular awareness of nuclear safety concerns and a private cause of action for individuals harmed by nuclear radiation, Justice Billings argued that the statutory scheme was open-ended on the issue in suit. ${ }^{48}$

The tension between the formalist and purposivist themes within legal process was soon exploited by critics from both the right and the left. On the right is the Chicago School law-and-economics movement, which takes as its starting point the legitimacy of our pluralist political system and the socioeconomic status quo and focuses on the comprehensive efficiency of different legal rules. ${ }^{49}$ Law and economics has broadened intellectual discourse in law, exposing the question-begging features of both traditional and process approaches. A law-andeconomics approach to Warshow, for example, would be less interested in the elements of the necessity defense (formalism) and the proper institution to determine nuclear risks (process theory), and more interested in the underlying structural issues. A major issue would be: looking at the general problem ex ante, what legal rule yields the incentives for environmentalists (alerting us to potential dangers), for regulators (who may be subject to rent-seeking pressure), and for the managers of the nuclear reactor that will result in an efficient allocation of resources to preventing disasters? For Richard Posner and other law-and-economics scholars of the 1960s and 1970s, legal process theory was not asking relevant questions and offered no rigorous methodology for making significant policy judgments such as the one presented in Warshow.

On the left, CLS scholars criticized process ideology for its ten-

46. 138 Vt. at 32, 410 A.2d at 1006 (Billings, J., dissenting).

47. $138 \mathrm{Vt}$. at $32,410 \mathrm{~A} .2 \mathrm{~d}$ at 1006 . See infra notes 86-99 and accompanying text for our analysis of the circularity always possible in legal process analytics.

48. $138 \mathrm{Vt}$. at $32-33,410 \mathrm{~A} .2 \mathrm{~d}$ at 1006.

49. In this article, we shall mainly discuss Chicago School law and economics, which takes as its starting point the assumed legitimacy of status quo institutions and allocations of power. Early classics include G. CALABRESI, THE Cost of ACcIDENTS: A Legal aND Economic ANALYSIS (1970); R. POSNER, The ECONOMIC ANAL ysis OF LAW (1972). See also R. PosNer, THE ECONOMICS OF JUSTICE (1981). 
dency to depoliticize social issues by channeling inquiry into procedural discourse and challenged the normative prong of process theory by arguing that the ethical bases for deference under the principle of institutional settlement were just as controversial as substantive decisionmaking and in any event they were analytically inseparable. As CLS described process theory, it reflected a particular status quo slanted ideology (the deference to "duly established procedures") for legitimating as neutral and rational basic social conditions of American life. Process theorists lacked a critical basis on which to distinguish legitimate from illegitimate institutional decisionmaking. Notwithstanding its claims toward neutral principles and results, legal process theory is no better than common law formalism at yielding determinate results based upon democratically made decisions. A critical approach to Justice Hill's Warshow concurrence would argue that the decisions made by democratic majorities do not support Justice Hill's deference to the regulatory safety rules. Even under legal process assumptions, Justice Hill's result does not necessarily follow, because there was no indication that the legislature expected (1) the regulatory regime entirely to preempt the common law defense of necessity, (2) the regulatory regime to foreclose alternatives in the case of emergency, or (3) anyone to defer to the regulatory regime if it broke down. On the whole, there is even a countermajoritarian tone to the Warshow concurrence: by taking the case away from the jury, the judiciary removed this public issue from the only "representative" body that was available, in deference to a legislative intent made up by a bunch of unelected judges.

CLS and law and economics were powerful alternative visions to public law issues. The reaction of mainstream academics has been ambivalent. Most have rejected what appeared to them "extremist" or "ideologically charged" movements on the right and the left.so Yet some mainstream scholars have recognized the problems with traditional legal process theory suggested by law and economics and CLS and have sought to reinterpret the legal process tradition in light of these criticisms, and in light of new learning in political theory, history, and philosophy.

\section{The "New" Legal Process Agenda for Public Law}

The Hart and Sacks legal process materials continue to define the pedagogical and intellectual agenda for most American public law 1 (1986).

50. See, e.g., B. ACKerman, supra note 1; Fiss, The Death of the Law, 72 CoRnell L. REV. 
around law's purposivism, institutional relationships, and proper procedures. ${ }^{51}$ Hence, it may be more appropriate to talk about "new legal process" 52 than about any truly "New Public Law." Even if that is so, public law discourse in the 1970s and 1980s was not just a rehashing of Hart and Sacks. Instead, it refined and developed their themes in response to new problems, to new theories and information, and to the attacks of law and economics and CLS. Indeed, recent public law scholarship is characterized by a tendency to engage with extralegal sources and other academic disciplines. Hence, public law scholarship in the 1980s has drawn extensively from extralegal work in civic republicanism, ${ }^{53}$ theology, ${ }^{54}$ feminism, ${ }^{55}$ hermeneutics, ${ }^{56}$ pragmatism, ${ }^{57}$ and public choice theory. ${ }^{58}$

The relationship between legal process theory and these extralegal theories is complex. The wider intellectual compass provided by these

51. Although the Hart and Sacks materials were never published, they have spawned a generation of important cases and materials books that approach subjects from a comprehensive institutional process perspective. Consider not only books on civil procedure, e.g., R. FIELD \& B. Kaplan, Materiats for a Basic Course in Civil Procedure (1953) (a classic now in its sixth edition, with Kevin Clermont as coauthor), administrative law, e.g., R. CASS \& C. DivER, Administrative LAW: CASES AND MATERIALS (1987); S. BREYER \& R. STEWART, ADMINIStrative Law and Regulatory Policy: Problems, Text, and Cases (1979); J. Mashaw \& R. Merrill, Introduction to the American Public law System: Cases and MATERIALS (1975), and legislation, e.g., W. EsKRIDGE \& P. FRICKEY, CASES AND MATERIALS on Legislation: Statutes and the Creation of Public Policy (1988), but also books on what might have been considered more "substantive" fields. E.g., T.A. ALEINIKOFF \& D. MARtin, Immigration: Process and Policy (1985); J. Areen, P. King, S. Goldberg \& A. CAPRoN, LAW, SCIENCE, AND MEdICINE (1984); R. FINDLEY \& D. FARBER, ENVIRONMENTAL LAW: CASES AND MATERIALS (1981).

52. See Weisberg, supra note 15; Eskridge \& Frickey, supra note 15, at 693; McDougall, Social Movements, Law, and Implementation: A Clinical Dimension for the New Legal Process, 75 CoRnell L. Rev. 83 (1989); Rodriguez, The Substance of the New Legal Process (Book Review), 77 Calif. L. Rev. 919 (1989).

53. See Michelman, The Supreme Court, 1985 Term - Foreword: Traces of Self-Government, 100 HARv. L. REV. 4 (1986); Sherry, Civic Virtue and the Feminine Voice in Constitutional Adjudication, 72 VA. L. Rev. 543 (1986); Sunstein, Beyond the Republican Revival, 97 YALE L.J. 1539 (1988).

54. See Cook, Beyond Critical Legal Studies: The Reconstructive Theology of Dr. Martin Luther King, Jr., 103 HARV. L. REv. 985 (1990); Cover, The Supreme Court, 1982 Term Foreword: Nomos and Narrative, 97 HARV. L. REV. 4 (1983).

55. See C. Mackinnon, Toward a Feminist Theory of the State (1989); Minow, The Supreme Court, 1986 Term - Foreword: Justice Engendered, 101 HARV. L. REV. 10 (1987); Radin, Market-Inalienability, 100 HARV. L. REv. 1849, 1921-36 (1987).

56. See INTERPRETING LAw AND LITERATURE: A HeRMENEUTIC REAdER (S. Levinson \& S. Mailloux eds. 1988); Interpretation Symposium, 58 S. CAL. L. REv. 1, 35-275 (1985); Eskridge, Gadamer/Statutory Interpretation, 90 ColuM. L. REV. 609 (1990).

57. See R. Posner, The Problems of JURISPRUdence (1990); Symposium on the Renaissance of Pragmatism in American Legal Thought, 63 S. CAL. L. REV. 1569 (1990); Farber, Legal Pragmatism and the Constitution, 72 MINN. L. REv. 1331 (1988); Patterson, Law's Pragmatism: Law as Practice \& Narrative, 76 VA. L. REV. 937 (1990).

58. See D. Farber \& P. Frickey, Law and Public Choice: A Critical IntroducTION (1991); Symposium on the Theory of Public Choice, 74 VA. L. REv. 167 (1988). 
theories has lent legal process analysis more critical bite, somewhat greater concern about substantive justice, and an intellectual vocabulary for liberal process theorists to develop their arguments for progressive coherence and purposivist law. As this description suggests, progressive rather than conservative scholars have been quick to utilize these particular extralegal theories, and these scholars are often ones who are more sympathetic to CLS than to law and economics. Yet they try to remain faithful to the legal process agenda for public law scholarship and, more significantly, have deployed extralegal theories in a legal processy way. Paralleling the old legal process emphasis on purposive law, proceduralism, and institutional competence, new legal process scholarship emphasizes the dynamics of purposive law (republicanism, hermeneutics), public deliberation (republicanism) and its structural features or biases (public choice theory), and a dialogic approach to truth (feminism, hermeneutics, pragmatism). The agenda is still recognizably legal process, but with a distinct emphasis on its progressive features and on arguments drawn from these extralegal theories.

\section{The Dynamics of Purposive Law}

Hart and Sacks reconceptualized law as dynamic. Thus, judges adapt and rethink common law categories when they apply them to new problems and social settings; statutory meaning evolves over time as judges and agencies implement and interpret the statutes; and the interaction of private parties, the legislature, courts, and agencies keeps the law in a constant state of flux. Reflecting the views of subsequent conservative process thinkers, Justice Hill's concurring opinion in Warshow emphasized that legal dynamics must be effected slowly and deliberately by the elected branches of government. Justice Billings' dissenting opinion reflected a more progressive process perspective, boldly rethinking a regulatory problem based upon new information and the challenge of the case. New legal process scholarship has more systematically pursued the dissent's purposive approach. Consider the following sampler:

a. Dynamic statutory interpretation. Legal process theory argued that judges should interpret statutes by choosing the interpretation most consonant with the statutes' purposes. ${ }^{59}$ This approach is an inherently dynamic alternative to one based upon the legislature's origi-

59. H. HART \& A. SACKS, supra note 2, at 166-67, 1179-203; see also Frankfurter, supra note 2; Radin, supra note 55. More recent elaborations include J. HURST, DEALING WITH STATUTES (1982); R. Dickerson, THe INTERPRETATION aNd APPLication of STATUTES (1975); S. MERMin, LAW AND THE LEGAL SYSTEM 255-70 (2d ed. 1982). 
nal intent: because society, law, and the nature of the problem change over time, effecting the statute's purpose might lead to statutory developments not contemplated or even rejected by the statutory drafters. Although Hart and Sacks contemplated this possibility, ${ }^{60}$ their more conservative followers were disturbed by the countermajoritarian nature of judicial "amendment" of commands enacted by the legislature. The 1980s witnessed a strong revival of theories of "dynamic statutory interpretation."61

The arguments for dynamic statutory interpretation include the traditional legal process arguments, focusing on the institutional competence of courts to update statutes. ${ }^{62}$ But unlike Hart and Sacks, newer legal process writers rest the case for dynamic statutory interpretation upon broader theories of meaning and politics. ${ }^{63}$ Like biblical, literary, and aesthetic interpretation, statutory interpretation is an interaction between a past text and a present interpreter; that interaction yields meaning that changes over time. The political legitimacy of dynamic, as opposed to static, statutory meaning is supported by arguments from civic republicanism and public choice theory. If law's legitimacy rests upon its ability to serve the common good (republicanism) and if the legislative process does not systematically update statutes in a satisfactory way (public choice), then it is the responsibility of statutory interpreters to apply old statutes to new problems creatively - and dynamically.

One consequence of the new focus has been a renewed emphasis on what is in fact the "best" or most sound policy result. ${ }^{64}$ Consistent with but going beyond the dissenting opinion in Warshow, dynamic theory in the 1980s would argue that regulatory statutes should be interpreted with an understanding of the new learning about grave risks posed by nuclear power, risks that were apparently underap-

60. See H. HART \& A. SACKS, supra note 2, at 1203-15 (the women jurors cases).

61. See Eskridge, Dynamic Statutory Interpretation, 135 U. PA. L. REv. 1479 (1987); Frickey, Congressional Intent, Practical Reasoning, and the Dynamic Nature of Federal Indian Law, 78 CaLIf. L. Rev. 1137 (1990); Farber \& Frickey, Legislative Intent and Public Choice, 74 VA. L. Rev. 423 (1988); Macey, Promoting Public-Regarding Legislation Through Statutory Interpretation: An Interest Group Model, 86 CoLuM. L. REv. 223 (1986); Patterson, Interpretation in Law: Toward a Reconstruction of the Current Debate, 29 VILL. L. REv. 671 (1984); Sunstein, Interpreting Statutes in the Regulatory State, 103 HARV. L. REV. 405 (1989).

62. Eskridge, supra note 61, at 1523-29, 1533-38; see G. CALABRESI, A COMMON LAW FOR THE AGE OF STATUTES (1982) (boldly arguing that courts ought to be able to overrule obsolescent statutes the same way they overrule obsolescent judicial precedents).

63. See Eskridge, supra note 61, at 1506-11 (hermeneutics); id. at 1513-16 (republicanism); id. at 1516-23 (public choice).

64. See Aleinikoff, Updating Statutory Interpretation, 87 Mrch. L. REv. 20 (1988); Eskridge, Spinning Legislative Supremacy, 78 GEo. L.J. 319 (1989); Zeppos, Judicial Candor and Statutory Interpretation, 78 GEO. L.J. 353 (1989). 
preciated when the statutes were adopted and that the political process has been slow to correct (for public choice reasons). Although the concurring opinion may have been closer to the original understanding of the statute, to occupy the entire field of nuclear safety, the dissenting opinion's interpretation of the statute to allow citizens to protect themselves is a better interpretation, for substantive policy reasons. ${ }^{65}$

b. Implementation over time of intransitive statutes. Hart and Sacks recognized that different statutes entail different dynamics. For example, statutes setting forth detailed duties for private citizens work out very differently from statutes setting forth highly general directives to agencies to implement. ${ }^{66}$ Legal process theory in the 1950 s focused mostly on transitive statutes whose directives are addressed directly to the citizenry, but recent scholarship explores the interesting ways in which intransitive statutes (mainly, those addressed to agencies) evolve. ${ }^{67}$ A substantial literature explores the related question of court-agency dynamics: how much deference should a court give to an agency interpretation of its intransitive statute? The prevailing approach today by both courts and commentators elaborates upon the traditional legal process position of deference to agencies, ${ }^{68}$ which was also a working assumption of the Warshow concurrence.

65. Yet we regret the dissent's weak reasoning. For example, the dissent invokes the musty canon that, absent a clear legislative statement, statutes should not be interpreted to change the common law. State v. Warshow, 138 Vt. 22, 32-33, 410 A.2d 1000, 1006 (1979) (Billings, J., dissenting). This canon has been largely discredited in the era of the regulatory state and in our view has malign social consequences in its preservation of outmoded common law baselines. Other statutory provisions invoked by the dissent are simply not on point and do not even convey a general policy flavor supporting the dissent. We do agree with the dissent that there is no necessary implication from the statutory scheme that the common law cannot be left free to evolve.

66. H. HART \& A. SACKS, supra note 2, at 188-89; see also id. at 169-71. We should note that these materials pay much less attention to the administrative process than the judicial, legislative, or executive process, which the editors regretted. Id. at 1092.

67. The transitive/intransitive distinction originates with Rubin, Law and Legislation in the Administrative State, 89 Colum. L. REv. 369 (1989). A more recent article expanding this distinction is Strauss, Relational Readers of Intransitive Statutes: Agency Interpretation and the Problem of Legislative History, 66 CHI.-KENT L. REV. (forthcoming).

68. See, e.g., Chevron, U.S.A., Inc. v. NRDC, 467 U.S. 837, 843 (1984) ("[T] he court does not simply impose its own construction on [an intransitive statute] .... Rather, if the statute is silent or ambiguous with respect to the specific issue, the question for the court is whether the agency's answer is based on a permissible construction of the statute.") (footnotes omitted); $H$. HART \& A. SACKS, supra note 2, at 1417 ("An interpretation by an administrative agency charged with first-line responsibility for the authoritative application of the statute should be accepted by the Court as conclusive, if it is consistent with the purpose properly to be attributed to the statute, and if it has been arrived at with regard to the factors which should be taken into account in elaborating it."). The leading legal process defense of judicial deference to agencies is found in Diver, Statutory Interpretation in the Administrative State, 133 U. PA. L. REV. 549 (1985). For a critique, see Farina, Statutory Interpretation and the Balance of Power in the Administrative State, 89 ColuM. L. REv. 452 (1989) (arguing that judicial deference to agencies allows power to be skewed in favor of the executive branch). 
Most new legal process scholarship has shown a skeptical approach to agencies more consistent with the Warshow dissent than with the concurrence. Public choice theory, for example, suggests systematic dysfunctions in agency policymaking that undermine recent scholars' willingness to give agencies blanket deference. ${ }^{69}$ Scholars criticize judicial deference to agency decisions as an abdication of judicial responsibility to reason and good policy. ${ }^{70}$

c. Law as dynamic coherence. Given Hart and Sacks' assumptions about interdependence and the importance attributed to principles and policies in law, legal process thinkers naturally emphasized coherence arguments. Law should seek consistency, and a legal argument on an unsettled issue is strengthened by its coherence with existing law. Thus, "[d]oubts about the purposes of particular statutes ... must be resolved, if possible, so as to harmonize them with more general principles and policies" of law. ${ }^{71}$

There are some striking similarities between the legal process synthesis of the 1950s and Ronald Dworkin's theory of "law as integrity," which posits that a judge interpreting a statute, the Constitution, or a common law decision has a duty to render an interpretation that best "fits" the text and overall principles of law. ${ }^{72}$ Dworkin's theory relies on the legal process distinction between "policies" and "principles" and on the importance of coherence arguments in law. The close link between Dworkin's theory and the legal process synthesis may help explain Dworkin's prominence, for his work explores the classic legal process themes through a more systematic analytical philosophy. Yet, Dworkin's work is not "just" legal process, for it is self-consciously evaluative. The judge must make the legal text the "best it can be," and Dworkin realizes that this means the judge must be a substantive critic as well as a process synthesizer.

69. Stewart, The Reformation of American Administrative Law, 88 HARV. L. REV. 1667 (1975).

70. See Farina, supra note 68.

71. H. HART \& A. SACKS, supra note 2, at 167. Hart and Sacks state:

The court's last resort, when doubt about the immediate purpose of a statute remains, is resort to an appropriate presumption drawn from some general policy of the law.

This is likely to be its only resort when the question concerns more nearly ultimate policy, or the mode of fitting the statute into the general fabric of the law.

Id. at 1416; see also id. at 1413 (policy of clear statement "forbids a court to understand a legislature as directing a departure from a generally prevailing principle or policy of the law unless it does so clearly").

72. "Law as integrity" is developed in R. Dworkin, LAw's EMPIRE (1986). Wellman, supra note 15, has argued in detail that Dworkin's work before Law's Empire (especially R. Dworkin, The Model of Rules ( $I$ \& II), in TAKING RIGHTS SERIOUSLY 14-80 (1977)) is very similar, if not identical, to H. HART \& A. SACKS, supra note 2. Note here that Dworkin graduated from the Harvard Law School in 1957, at the apogee of legal process' formative period. 


\section{Public Deliberation Reinvigorating the Political and Regulatory Process}

One limitation of legal process theory was its underappreciation of structural biases in the political system. Feminism and critical race theory have highlighted the attitudinal biases of traditional lawmaking, and public choice theory suggests the nature of some institutional dysfunctions. Republicanism insists that government be structured to nurture and respond to public values. As the dissenting opinion in Warshow makes clear, however, a concern with institutional and procedural biases is consistent with a progressive legal process approach that insists that government subserve the purposes it holds out to the citizenry. An important goal of the new legal process is to think about structural solutions and "adopt new strategies for achieving national goals in lieu of the centralizing command and control techniques" of the New Deal. ${ }^{73}$ The structural solutions usually involve the application of the checks and balances concept. ${ }^{74}$ Consider the following examples.

a. New checks on bureaucratic decisionmaking. Just as dysfunctions in private ordering call forth regulation, usually by agencies, so should regulation be devised to deal with dysfunctions in public ordering. Here, legislatures or agencies are often the culprits, and progressive legal process scholars have advocated novel solutions. One might read the dissenting opinion in Warshow this way: because there was tangible reason to believe that the nuclear regulatory agencies were not vigilantly protecting the public's safety, the court should have been open to the evidence of citizens monitoring the safety of the reactor. Trial of the necessity defense should have been allowed to ventilate this issue, especially given the potentially enormous public risks.

A similar theme informs scholarship about the "structural injunction,"75 which responds to the perceived need for judges to enter increasingly detailed orders in school desegregation cases, because the political process (for structural reasons) was unwilling to make serious movement to the unitary school system mandated by Brown v. Board of Education. ${ }^{76}$ Similarly, new legal process scholars agree that more aggressive judicial review might ameliorate the systemic biases of

73. Stewart, Mådison's Nightmare, 57 U. CH1. L. REv. 335, 352 (1990).

74. See, e.g., Carter, Constitutional Improprieties: Reflections on Mistretta, Morrison, and Administrative Government, 57 U. CHI. L. REV. 357 (1990).

75. See O. Fiss, The Civil Rights Injunction (1978); R. Cover, O. Fiss \& J. Resnik, PROCEDURE 227-351 (1989) (case study of desegregation injunction); Chayes, The Role of the Judge in Public Law Litigation, 89 HARV. L. REV. 1281 (1976).

76. 347 U.S. 483 (1954). 
agencies, ${ }^{77}$ as well as tackle some of the problems of administrative inaction. ${ }^{78}$ Perhaps more important has been the administrative law scholarship advocating a stronger role for executive or legislative review of agency decisions, as a better way to correct regulatory misfires. 79

b. Regulatory strategies. Hart and Sacks were interested in alternative strategies for regulating collective action problems, through private groups or administrative agencies or citizen lawsuits or some mix, but they tended to ignore issues of comparative regulatory strategies - the advantages and disadvantages of different strategies for different problems. The various opinions in Warshow are representative of this blind spot; even the dissenting opinion views regulation along the fairly simple lines of agency rulemaking and citizen enforcement. An important theme of new legal process scholarship considers the rich menu of regulatory strategies from which to choose and the relative fit between social problem and regulatory strategy.

Recent scholarship focusing on regulatory failure argues that the biggest problem of regulation is that regulatory weapons are not wellsuited to dealing with the problems attacked. ${ }^{80}$ Different justifications for regulation (market failure versus social justice, for example) will usually require different regulatory strategies (antitrust and disclosure rules versus distributive laws in our example). A major problem for the regulatory state is matching justifications for regulation with strategies. Another challenge is approaching each regulatory strategy more critically, to determine whether or not it works and whether or not its costs outweigh its benefits.

c. Reinvigorating the political process. Although the legitimacy of legal process theory rested in part upon the assumption that America enjoys a working democracy, legal process thinkers were not very curious about the political system in this country. As an example, none of the opinions in Warshow reveals the slightest doubt that we have a well-functioning democracy, in which the legislature legitimately represents and is responsive to the will of the people. Even the dissenting

77. The seminal piece is Stewart, supra note 69. .

78. See Sunstein, Deregulation and the Hard-Look Doctrine, 1983 SUP. CT. REV. 177; Sunstein, Reviewing Agency Inaction After Hechler v. Chaney, 52 U. CHI. L. REv. 653 (1985).

79. See Bruff, Presidential Power and Administrative Rulemaking, 88 YALE L.J. 451 (1979); Cutler \& Johnson, Regulation and the Political Process, 84 YALE L.J. 1395 (1975); Strauss \& Sunstein, The Role of the President and OMB in Informal Rulemaking, 38 ADMIN. L. REv. 181 (1986).

80. S. Breyer, Regulation and Its Reform (1982); Breyer, Analyzing Regulatory Failure: Mismatches, Less Restrictive Alternatives, and Reform, 92 HARV. L. REV. 547 (1979). A similar theme is pursued in C. SUNSTEIN, AFTER the RIGHTS Revolution: RECONCEIVING THE REGUlatory STATE (1990). 
opinion, which alludes with vague approval to the defendant's argument that "although there is a comprehensive regulatory scheme, it had failed,"81 neglects to pursue its own suggestion. Strikingly, the dissent fails to note the irony that the majority opinion snatches the Warshow necessity defense away from the jury, "We the People," based upon antiquarian doctrine made up by unelected judges!

Recent intellectual developments in public law scholarship suggest that greater emphasis should be placed on the operation of the political system: civic republicanism values a politically aware and involved citizenry; feminism and critical race theory question the legitimacy of what were once thought to be "majoritarian" decisions; and public choice theory challenges the accepted conventions of "majority rule." Thus far, new legal process scholarship has been notably slow in pursuing these themes, although new legal process scholarship is emerging around issues of campaign finance, ${ }^{82}$ bribery and legislative ethics, ${ }^{83}$ direct democracy, ${ }^{84}$ and the role of local government in a federal republic. ${ }^{85}$

\section{Judicial Review as Moral or Political Dialogue}

Although legal process theory contemplated substantial judicial lawmaking through creative statutory interpretation, it considered such lawmaking necessarily "interstitial." Consistent with the relativist theory of democracy, legal process theory recognized that a "counter-majoritarian difficulty" inhered in any judicial invalidation of legislative or administrative rules. ${ }^{86}$ The legal process assumption that courts would not often invalidate the work product of the majoritarian political branches was arguably contrary, however, to the judicial activism of the 1960s and 1970s. From this apparent inconsistency sprung a substantial literature justifying or criticizing activist judicial review along legal process lines.

This challenge has been most acute in connection with Brown $v$. Board of Education. ${ }^{87}$ The legal process synthesis was almost com-

81. Warshow, 138 Vt. at 32, 410 A.2d at 1006 (Billings, J., dissenting).

82. See Blum, The Divisible First Amendment: A Critical Functionalist Approach to Freedom of Speech and Electoral Campaign Spending, 58 N.Y.U. L. REv. 1273 (1983); see generally W. ESKRIDGE \& P. FRICKEY, supra note 51, at 209-39.

83. See Lowenstein, Political Bribery and the Intermediate Theory of Politics, 32 UCLA L. REV. 784 (1985); see generally W. ESKRIDGE \& P. FRICKEY, supra note 51, at 164-209.

84. See W. EsKRIDGE \& P. FRICKEY, supra note 51, at 520-59.

85. See Macey, Federal Deference to Local Regulators and the Economic Theory of Regulation: Toward a Public-Choice Explanation of Federalism, 76 VA. L. REv. 265 (1990).

86. A. Bickel, THE Least DaNGerous BraNCH 16 (1962).

87. 347 U.S. 483 (1954). 
pletely oblivious to the role of constitutional law in ending apartheid in the United States. The most important legal process thinker to address Brown in the 1950s (Herbert Wechsler) confessed that he could find no "neutral principle" to justify the result. ${ }^{88}$ Wechsler's immediately famous neutral principles article faithfully expressed the legal process consensus in constitutional law (repudiation of Lochner and judicial value-imposition), but, by questioning a decision that seemed so unquestionably right, the article cast a pall over the entire legal process enterprise, because it revealed its conservative underside.

Legal process thought could not avoid the Brown issue in the 1960s, but it could never quite explain Brown, except as a case uniquely compelled by unusual circumstances. ${ }^{89}$ Much of the "newer" legal process work in the 1970s and 1980s was directly or indirectly aimed at this very problem.

John Hart Ely's Democracy and Distrust was the first impressive defense of Brown through the perspective of legal process theory. ${ }^{90}$ His "representation-reinforcement" theory accepted the countermajoritarian difficulty as the central problem of judicial review, especially when the Court invalidates legislation based upon the "opentextured" provisions of the Constitution such as the equal protection clause. ${ }^{91}$ The Court can escape this difficulty by a reasoned elaboration of those provisions based upon principles derived from the Constitution and its underlying structure. ${ }^{92}$ That structure is proceduralist, and the role of the Court is to protect the integrity of the political process. ${ }^{93}$ The Court is a "perfecter of democracy" and, hence, is justified in striking down laws that cut off the channels of political change (voting restrictions), that seek to limit dissent (prior restraints, repression of unpopular stands), ${ }^{94}$ or that penalize a "discrete and insular minority" which has been systematically excluded from the political process (as in the Brown cases). ${ }^{95}$

88. See Wechsler, supra note 2, at 34 (admitting that he "like[d]" the result in Brown but believed that some neutral principle for the result had to be found to render it legitimate). See generally Peller, supra note 4.

89. See A. BICKEL, supra note 86.

90. J. ELY, DEMOCRACY AND Distrust: A Theory of Judicial ReView (1980); see also

J. Choper, Judicial Review and the National Political Process (1980).

91. ELY, supra note 90, at 1-9.

92. Id. at 88-104.

93. This is a classic legal process idea, expressed most clearly in the "due process of lawmaking" literature. "[T] he central function of judicial review" should be "to guarantee the democratic legitimacy of political decisions by establishing the essential rules of the political process." Linde, Due Process of Lawmaking, 55 NEB. L. REv. 197, 251 (1976); see W. EsKRIDGE \& P. FRICKEY, supra note 15, at 340-67 (elaborating on this line of constitutional writing).

94. ELY, supra note 90 , at 105-34.

95. Id. at $75-77,135-79$. 
Representation reinforcement is in some ways the apotheosis of legal process theory, at least as applied to constitutional issues. Even as Ely's approach has become mainstream, its vulnerability to the same formalist/purposive analytic has been apparent. One could identify the legitimating procedures for democratic decisionmaking in formalist fashion, by simply seeing if people have voted for governmental officials. Or one could ask in purposive fashion if the quality of life and power relations in American society is characterized by the kind of freedom that makes self-determination attractive and possible. The process-inspired move to representation-reinforcement cannot escape substantive value choices since they are implicated in the image of democratic representation itself. Scholarly commentary has thus tended to focus on the proceduralist impulse behind Ely's synthesis. The Constitution is not just a proceduralist document; 96 indeed its central point, representative democracy, is a value choice. Reading substantive values out of the Constitution is something like reading God out of the Bible. Even if the Constitution were essentially a proceduralist document, nothing in it suggests that courts ought to use process arguments to invalidate legislation. ${ }^{97}$ And even if the Court were truly the "perfecter of democracy," neither it nor Ely has a coherent or informed theory of democracy that provides useful guidelines regarding when intervention is justified. ${ }^{98}$

Given the difficulties with Ely's synthesis, the past ten years have seen a proliferation of theories of judicial review premised upon the idea that constitutional "[a]djudication is the social process by which judges give meaning to our public values." 99 Most of these theories of

96. The heart of Ely's book is its elegant demonstration that some of the apparently substantive protections of the Constitution - such as the establishment clause and the anti-self-incrimination clause - are just as much procedural provisions as substantive ones. Yet the same demonstration could be made for most of the procedural provisions. For example, the free speech clause protects individual dignity and privacy interests (recall Griswold), as well as some market interests (recall Goldfarb and Bigelow), and so cannot be viewed as just protecting access to the political process. All that Ely's elegant demonstrations really suggest is the incoherence between the substance-procedure distinction. Once that distinction collapses, so does Ely's demonstration.

97. Especially in cases like Brown, where the constitutional text suggests that Congress, and not the Court, ought to be the main enforcer of the equal protection clause.

98. Ely's adoption of the Carolene Products idea that the Court ought to protect discrete and insular minorities, because they will not be able to protect themselves in the political process, is not defended upon any political theory whatsoever and in fact is probably politically naive. Compare Ackerman, Beyond Carolene Products, 98 HARv. L. Rev. 713 (1985) with Farber \& Frickey, Is Carolene Products Dead? Reflections on Affirmative Action and the Dynamics of Civil Rights Legislation, 79 CALIF. L. REV. (forthcoming 1991).

99. Fiss, The Supreme Court, 1978 Term - Foreword: The Forms of Justice, 93 HARV. L. REv. 1, 2 (1979). For other leading public values theories of judicial review, see M. PERRY, THE CONSTITUTION, THE COURTS, AND HUMAN RIGHTS: AN INQUIRY INTO THE LEGITIMACY OF Constrtutional PolicymakiNg BY THE JUdiciaRY (1982); Ackerman, The Storrs Lectures: 
judicial review are consciously inspired by Brown. Among the lessons of Brown are the importance of our tradition of ongoing moral development, the "prophetic" role of courts in stimulating this ongoing moral dialectic in light of structural impediments elsewhere in the political process, and a diminished concern for the legal process countermajoritarian difficulty given our nation's substantive commitments.

\section{Beyond Legal Process: New Public Law}

Although our first account of the jurisprudence of public law discourse probably approximates the conventional wisdom, we think it does not quite capture everything that has been going on in public law for the past ten or fifteen years. Our second account deemphasizes the sense of continuity in the preceding account and instead emphasizes the rupture between the legal process generation and our own generation. The recent interest of mainstream legal academics in feminism, civic republicanism, critical race theory, public choice theory, and hermeneutics is no accident, nor is it merely a faddish response to the law-and-economics and CLS problems with traditional process theory. Instead, this interest is a manifestation of dissatisfaction with legal process assumptions in light of the events of our lifetime.

The heirs of the legal process scholars were also the heirs of the civil rights movement, and the events of our generation sharpened the critique of legal process' assumptions and its flight from substance. Post-legal process scholarship has returned to substantive discussion, but with a variety of twists. Conservative law-and-economics scholars objected to the ad hoc craftlike quality of the legal process approach; they sought to develop a more scientific (less prudential) methodology for achieving the utilitarian goals implicit in legal process. CLS scholars objected to the status quo orientation of legal process; they sought to repoliticize what the process theorists had taken as merely technical or functional. A centrist post-legal process group - situated between law and economics and CLS - has emerged as well, and this group might be called a New Public Law movement. What makes New Public Law something more than just more and newer legal process is its conscious rejection of the pluralist political features of legal process theory. Where even progressive legal process scholars tended to as-

Discovering the Constitution, 93 YALE L.J. 1013 (1984); Burt, Constitutional Law and the Teaching of the Parables, 93 YALE L.J. 455 (1984); Michelman, Law's Republic, 97 YALE L.J. 1493 (1988); Sunstein, Public Values, Private Interests, and the Equal Protection Clause, 1982 SuP. CT. REv. 127. Tushnet, Anti-Formalism in Recent Constitutional Theory, 83 MicH. L. REv. 1502 (1985), is an excellent critical analysis of these theories. 
sume that people's preferences are predetermined, that politics primarily consists of the aggregation or compromises of preferences, and that norms are less important than process, New Public Law scholars of the 1980s suggested the outlines of an antipluralist conception of law, where people's preferences are formed through politics and not prior to it, where law and politics are socially constructed, and where law and politics are heavily normative.

\section{A. After Legal Process...}

The generation of baby boomers that grew up after World War II and the Korean War was thrown into a world in which the assumptions of legal process and its apologetic agenda were open to question. To the legal process mind, the world was a manichaean world of ourgood-democracy against their-bad-dictatorship, and legal process was the justifying theory of that perceived goodness and rationality. A new generation has reinterpreted that world as a schizophrenic world of good rhetoric masking bad reality, and many of us came to see the legal process not only as a mask, but as a mode of oppression. We hope to capture here the way in which the intellectual developments after the 1950s connected with the events of that period to create a generation that wants something more than legal process.

The intellectual consensus that our government was truly an open, pluralist, free democracy ended in the late 1950s. While most academics in the early 1950 s readily accepted the optimistic scenario that our pluralist government was broadly representative of the nation's diverse groups and yielded policies that subserved the public interest (variously defined), this view came under attack in the latter part of the decade and was widely disbelieved in the 1960s. An obvious problem with American pluralism was that the tolerant ideology of openness and experimentation served to obscure the realities of social determination along lines of race, gender, and sexual orientation. As one critic noted, "[t]he flaw in the pluralist heaven is that the heavenly chorus sings with a strong upper-class accent." 100

Theoretically, a number of interesting interpretations could explain this phenomenon. Public choice theory suggested some reasons for the asymmetries of American pluralism: interest groups are much more likely to organize and be politically salient if they are small,

100. E. Schattschneider, The Semisovereign People 35 (1960); see C. Mills, The Power EltTe (1956); D. CoRy [a pseudonym] The Homosexual in AMERica: A SubjectIVE APPROACH (1951); B. Freidan, The FEMININE MYSTIQUe (1960); G. MYRDAL, AN AMERICAN DilemMA (1944). This criticism is accepted today even by strong defenders of pluralism. E.g., R. Dahl, Dilemmas of Pluralist Democracy: Autonomy vs. Control 4043 (1982). 
wealthy, and homogeneous, and as a result the interests of most Americans are not well-represented in a pluralist system; the groups represented in the process tend to divide up the spoils of government (rents) through a process of logrolling. ${ }^{101}$ For example, a public choice explanation of the politics of nuclear regulation in Warshow .would emphasize the political power of the nuclear power industry (small numbers, very wealthy, and politically connected), as well as the difficulty that antinuclear protesters have in overcoming the free rider problem as they try to mobilize the public against the dangers of nuclear power. Public choice theorists tended to approach the dysfunctions of American pluralism in a nonevaluative way, but the same was decidedly not true of political scientists, some of whom questioned the legitimacy of a pluralism that seemed little more than a "democratic elitism."102 The political system that jailed the Vermont Yankee protesters was not necessarily one that represented the interests or desires of the people, and the court's result removed the only voice of ordinary people - the jury - from the case.

The political awareness and events of the 1960s reinforced these criticisms of pluralism as a closed system dominated by upper class white males, which actively suppressed rather than fostered openness and diversity in our public culture. The classic example was racial apartheid in the South (and parts of the North), in which the so-called pluralist political system perpetuated its own elites by segregating African-Americans from minimal educational opportunities, enjoyment of public facilities, housing, and jobs. ${ }^{103}$ Where the New Deal and legal process thought had been substantially blind to the scandal of apartheid, it galvanized our generation, as did the men and women who opposed it in the civil rights movement. In the 1960s, the critique of American democracy, begun in the civil rights movement, was broadened; racial apartheid was simply the most obvious evidence of the closure of pluralism. Also excluded and suppressed, though in varying degrees, were women, Hispanics, the urban poor, migrant workers, the handicapped, and gay men and lesbians; each of these groups

101. M. Olson, The Logic of Collective Action (1965); see J. Buchanan \& G. Tullock, The Calculus of Consent: Logical Foundations of Constitutional DemocRACY (1962); A. DOWNS, AN ECONOMIC THEORY OF DEMOCRACY (1957); E. Schattschneider, Politics, Pressures and the Tariff: A Study of Free Private ENterprise in Pressure Politics, as Shown in the 1929-1930 Revision of the Tariff (1935) (anticipating most of the themes of public choice theory).

102. P. Bachrach, The Theory of Democratic Elitism: A Critique (1967); see Davis, The Cost of Realism: Contemporary Restatements of Democracy, 17 W. PoL. Q., 37 (1964); Lowi, American Business, Public Policy, Case-Studies, and Political Theory, 16 WORLD POL. 677 (1964).

103. For early accounts of this travesty, see G. MYRDAL, supra note 100. 
in turn demanded recognition of their place in the political community in the 1960s or 1970s. This experience turned the relativist theory of democracy on its head. What was touted as a superior form of government because of its openness, tolerance, and diversity, was revealed to be a political system whose closure, bigotry, and artificially imposed homogeneity inspired sincere charges of fascism.

A related theoretical problem with the relativist or pluralist theory of democracy, and its accompanying legal process philosophy, was the way in which it denied possibilities for self-government and thereby drained democracy of its tranformative and energizing punch. ${ }^{104}$ That is, by defining "politics" as the relatively narrow and formalized conflict among organized economic groups within the legislature or administrative process, the ideology of political pluralism implicitly obscured the possibility of other forms of political struggle outside that process, of grass roots politics and community organizing, and of organizing politics around ideological issues rather than narrowly defined economic issues. For example, by treating the case as one of simple trespass and by suppressing the first amendment implications of the criminal prosecution, Warshow seemed to deny the intrinsically "political" nature of the protesters' activity.

Like the bias critique of pluralism, this suppression-of-politics critique resonated with the lived experience of the 1960s. Union-organizing within the workplace had long been an inspiring counterexample to pluralism's narrow conception of politics, but in the 1950s and 1960s the civil rights movement gained prominence as the classic counterexample. The movement broke many of the rules that guided pluralism, for it ignored economic interests and created an ideological community dedicated to abolishing apartheid, emphasized direct community action and resort to the courts rather than petitions to the legislatures that were effectively dead ends, and - most alarming of all from the pluralist/legal process perspective - engaged in disruptive activity such as "illegal" boycotts, marches, and sit-ins (just as in Warshow). This was disturbing to the legal process mentality, for the civil rights movement's effort to transform the larger community outside the ordinary political process conflicted with the principle of institutional settlement. "They" did not follow the proper procedures and thereby violated the special "oughtness" of the legal process state. "This is not how our system of government was meant to operate,"

104. W. Connolly, The Challenge to Pluralist Theory, in The Bias of Pluralism 3 (1969); see P. BACHRACH, supra note 102; Cunningham, Pluralism and the Class Struggle, 39 ScI. \& SocY. 385, 415-16 (1975-76). 


\section{proclaimed the Warshow concurrence. ${ }^{105}$}

By the late 1960s, the challenge to legal process pluralism had become substantially more direct. ${ }^{106}$ Although the mainstream civil rights movement had worked within the legal process to seek desegregation of schools through the courts and transformative legislation through Congress, events were nonetheless careening away from the accommodationist pluralist structure. Confrontationist tactics became more common, both by blacks seeking civil rights and by new oppositionist groups. Opponents of the war in Vietnam burned draft cards, refused to register for the draft, occupied campus buildings, and drenched military records with blood. Gay men and lesbians fought back when police staged a harassing raid on the Stonewall bar and invaded meetings of the American Psychiatric Association to protest its historic persecution. Pro-environment protesters closed down nuclear power plants by their sit-ins, as in Warshow. All of these groups were following a new antipluralist strategy of confrontation: Wasn't a confrontational strategy which disarmed the process of its diluting, delaying, and draining proceduralism a better strategy than one which accepted the process on its own biased terms?

The increasing public bitterness against the fruits of the legal process, especially apartheid and the Vietnam War, ties in with a third theme of the intellectual critique of democratic relativism. The critique focused on the pluralist/process flight from values and challenged democracy to prove its worthiness. By elevating process goals, such as stability of the ongoing political system, over substantive goals, ${ }^{107}$ and emphasizing a normless pragmatism, ${ }^{108}$ pluralism de-

105. Warshow, 138 Vt. at 28,410 A.2d at 1003 (Hill, J., concurring).

106. See generally Peller, Race Consciousness, 1990 DuKE L.J. 758.

107. The view of most pluralists in the 1950 s was that "[w]hat may be called public policy is actually the equilibrium reached in the group struggle at any given moment." Latham, The Group Basis of Politics: Notes for a Theory, 46 AM. Pol. SCI. REv. 376, 390 (1952); see H. SmIth, Democracy aND THE Public INTERest 77-93, 155-59 (1960) (public interest is equivalent to the results of a well-designed democratic process working in equilibrium); Sorauf, The Public Interest Reconsidered, 19 J. PoL. 616 (1957). Given the evidence of group asymmetry, this view of public policy became less normatively attractive for pluralist theory in the 1960 s and 1970s. Pluralist theory thereupon shifted its normative emphasis to the argument that its system of pluralistic preferences in continual interaction (bargaining, political conflict) contributes to the stability and moderation of society. See S. LIPSET, Political MAN: The Social BASEs of Politics 77-79 (1963); Miller, Pluralism and Social Choice, 77 AM. Pol. SCI. Rev. 734 (1983).

108. See P. BACHRACh, supra note 102, at 93 (because democratic theory is "explanatory rather than normative in approach," it reflects "a receptiveness toward the existing structure of power and elite decision-making"); E. PURCELL, supra note 4, at 269-70 ("Pragmatism required a broad set of social values that would provide the criteria both for what ought to be done and what was actually successful. Without a clear and critical political analysis, and with a fundamental prescriptive-descriptive confusion, pragmatically based relativist theory easily accepted the existent as its set of validating social ideals."). 
flected attention from the public good and indeed de-energized efforts to define or seek the public good. ${ }^{109}$ In the context of the mass mobilizations of the 1960s, it seemed morally empty for establishment figures to tell protesters, "Write your Congressman." Along these lines, consider the particular flatness of the Warshow concurrence: "I express no opinion as to the relative merits or demerits of nuclear energy, nor do I question the sincerity of the defendants' beliefs. All that I would hold is that this Court is not the proper forum to grant defendants the relief they seek." 110

The collapse of intellectual consensus about the relativistic theory of democracy finds its parallel in an erosion of confidence in legal process theory after the events of the 1960s. The vividness of the Hart and Sacks synthesis of post-New Deal jurisprudence, the image of a unified and progressive legal academy organized around core ideas shared by the enlightened world, gave way to feelings of partiality and rootlessness. When the artificially imposed 1950 s consensus about values collapsed in the 1960s, legal process had nothing to replace the lost consensus, except an increasingly empty proceduralism. As a result, legal process scholarship in the 1960 s unconsciously drifted into discussions of craft and technique, without any real sense that the scholarship was confirmed by or relevant to anything important. The legal process synthesis languished in the 1970s, as liberals (Ely, the Warshow dissent) traded arguments with conservatives (Bork, the Warshow concurrence) within the assumptions of the legal process analytic, but no longer with a sense that it made any real difference.

The situation was in fact worse than that. Just as legal process theory had achieved hegemonic status at many law schools, it fell under the fierce analytic assault of law and economics and CLS. Despite their great differences, these two movements had in common a thoroughgoing intellectual critique of the legal process hegemony they confronted. Both found the legal process synthesis lacking in analytical rigor, a modern theory of politics, and persuasive reasons for lawyers to continue to accept its conclusions. Although legal process sought to marginalize both law and economics and CLS as "extremist" ideologically driven factions - the strategy that had worked to discredit the realists and the formalists in the 1940s and 1950s - its

109. See Cochran, Political Science and "The Public Interest," 36 J. Pol. 327 (1974); P. BACHRACH, supra note 102, at 99-100 ("At the outset the democratic theorist must abandon explanatory theory as an approach to his subject. By adhering to it he tends to accept as unalterable the configuration of society as shaped by impersonal forces. . . . Instead, what we must acquire ... is a healthy dose of Promethean defiance against the illiberal and impersonal forces which tend to devastate us.").

110. Warshow, 138 Vt. at 28, 410 A.2d at 1003 (Hill, J., concurring). 
efforts failed, and the attacks on legal process exposed its emptiness and dearth of answers to modern problems.

Law and economics, for example, shared the legal process commitment to a status quo-oriented pluralism, but then demonstrated that legal process-endorsed conventional New Deal answers to social problems were normatively useless, based upon a systematic microeconomic theory that argued the market (the private sphere) would swallow up attempts at legal reform (the public sphere). CLS attacked the status quo orientation of legal process and argued that its efforts at legal reform were merely apologist efforts by ruling elites to create the illusion but not the reality of social justice; critical scholars systematically undermined the analytical tools by which legal process thinkers built their arguments, thereby exposing legal process to charges of class bias and elitism. Legal process had no systematic answers to the analytics of law and economics and CLS. Once the discussion shifted from process to substance, legal process had little to offer.

\section{B. Beyond Legal Process: Normativism and the New Public Law}

The collapse of legal process paved the way for a new generation of legal scholars to seize the middle ground between Chicago School law and economics, which struck many as normatively impoverished and apologetic, and CLS, which struck many as insufficiently affirmative in its agenda. New Public Law was the response of those in the baby boom generation for whom Brown is central to public law rather than marginal. New Public Law should be seen as a generational movement reflecting changes in our professional culture, assumptions about government, and aspirations about law (see Table 2 below). 
TABLE 2

From Common Law formalism to the New Public Law

Common Law Formalism (1890s-1900s)

Relatively Closed

(WASP Elites)

Lawyer as Hired Gun

Lawyers as Bastions of the Status Quo

\section{Common Law Ground \\ Rules}

Primacy of Private over Public

Formalism

Liberalism:

Community as Collection of Individuals

Market Values

Liberty

$\frac{\begin{array}{c}\text { Legal Process } \\ (1940 s-1950 s)\end{array}}{\text { Professional Culture }}$

Small Influx of Ethnic Lawyers

Lawyer as Public Servant

Lawyers as Reformers

Assumptions About Government
New Public Law (1970s-1980s)

\begin{tabular}{c} 
New Public Law \\
(1970s-1980s) \\
\hline
\end{tabular}

Substantial Influx of Lawyers of Different Race, Gender, Culture Public Interest Lawyering Lawyers as Restructurers of Status Quo

\section{Government Regulation New Forms of}

Regulation, or

Deregulation

Interaction of Private \& Public but Primacy of

Denial of Public/Private Public Interest

Distinction

Proceduralism

Normativism

Underlying Intellectual Structures

Purposivism:

Community as the State

Perfected Market Values

Practicality \& Neutrality
Public Values:

Community as Interacting Groups

Nonmarket Values

Equality

The typical New Public Law scholar is someone born into a wellto-do family between World War II and the War in Vietnam. He or she grew up in relative affluence, never served in the armed forces, and majored in a liberal arts subject at a tony undergraduate college. A part of his or her undergraduate experience was participation in protest rallies such as the one at Vermont Yankee, although like the Vermont Yankee protesters he or she was not likely to have been smacked in the face by a police officer or subjected to terrible inconvenience for these protest activities. An important reason for going to law school (often after graduate work in another discipline) was his or her desire to replicate the Brown experience he or she so admired: Law becomes one further means of protesting social injustice and perhaps doing something to rectify such injustices.

Our typical New Public Law scholar then attended an elite law school in the late 1960 s or 1970 s. $^{111}$ The law school environment at

111. Often Harvard or Yale. It seems worth noting that virtually all of these people would have been out of place in the Yale or Harvard Law Schools of the era of common law formalism, 
that time embodied the best of the legal process tradition, emphasizing a vigorously reformist approach to the status quo, whose overall legitimacy was broadly assumed. Often reflecting his or her own graduate school experience and the eclectic pedagogical agenda at the major law schools, ${ }^{112}$ the typical budding New Public Law scholar from the beginning of his or her academic career has been interested in intellectual developments outside of law, especially developments in political theory and economics. He or she is also an avid reader of CLS scholarship and is impressed with its vision but believes it is "too negative." 113 He or she thinks scholarship can contribute positive insights to law. The scholar has an ambitious vision of scholarship as not primarily doctrinal, but as integration of new thinking about government, politics, and law into legal topics (including doctrinal topics). His or her audience is not primarily the practitioner, nor is it the radical lawyer or even the public defender; instead, it is other boomer elites law professors, legislative counsel, journalists, and sundry intellectuals of the baby boom generation or later. The message of these scholars is that legal process is not enough in very important ways, at least implicitly for some of the reasons developed above.

The positive themes of New Public Law scholarship are by necessity somewhat eclectic (see Table 2 above), but we shall explore them in some detail here. ${ }^{114}$ The central difference between the New Public Law and legal process theory (even its progressive mode) is the New Public Law's self-conscious rejection of the ideology embodied in the relativist theory of democracy. The rejection of this ideology has freed New Public Law scholars to talk about law in the discourse of a competing ideology, "normativism,"115 which is antipluralist, antiformal-

because they were Jewish, or female, or black, or Hispanic, or gay, or some combination. About half of these people would have been out of place at those law schools during the legal process era, because they were female, or black, or Hispanic, or gay, or some combination. Although they came of age in a period when this heterogeneity was more common in the professional world, many of these scholars will have been subjected to insulting incidents by professionals prejudiced against them on grounds of race, sex, ethnicity, or sexual orientation. Notwithstanding their privileged upbringing, they may as a group be unusually sensitive to subtle forms of discrimination, inequality, and prejudice. On the other hand, many are neither particularly bitter nor angry about their brushes with prejudice. We want to be clear here that not all Jews, women, African-Americans, Hispanics, gay men, and lesbians have gravitated to New Public Law discourse. Many have embraced CLS. It does appear that both New Public Law and CLS are significantly more diverse than legal process and law and economics have traditionally been.

112. See Posner, The Decline of Law as an Autonomous Discipline: 1962-1987, 100 HaRv. L. REv. 761 (1987); Cook, supra note 54.

113. See, e.g., Fiss, supra note 50; McDougall, supra note 52, at 94-98.

114. This account has been guided by Eskridge, supra note 4; McDougall, supra note 52; Rodriguez, supra note 52; Rubin, The Practice and Discourse of Legal Scholarship, 86 Mich. L. REV. 1835 (1988).

115. A term suggested to us by Alex Aleinikoff and first used in Eskridge, supra note 4, at $964 \&$ n. 105 . 
ist, and strongly value-oriented. The remainder of this Part is an explication of normativism. In this section, we set forth the basic precepts of normativism, and develop its differences with progressive legal process theory by application to our Case of the Nuclear Protesters. Three precepts are critical to the New Public Law: (1) The legitimacy of law rests upon its normative content and not its procedural pedigree. (2) Law is not just purposive, but is formative, destructive, and transformative. (3) Law is dialogical practical reasoning. The next section will explore the third precept in greater detail, in the context of several identifiably New Public Law articles and in the context of the "Case of the Gay Rights Coalition."

\section{The Normativity of Law}

Common law formalism celebrated the neutrality of law as essential for the preservation of the security of the private domain. It strikes us as rather surprising that legal process - the comprehensive public law theory for the New Deal's regulatory state - also celebrated the neutrality of law, as practically useful in enabling people to live in an interdependent community. Both the concurring and dissenting opinions in Warshow emphasized the neutrality and objectivity of their interpretations of the common law and relevant statutes. New Public Law thinkers do not consider the law neutral and objective. In part, the denial of neutrality/objectivity is a descriptive claim, with several interesting twists. ${ }^{116}$ Law is contextual: it cannot be separated from society, its values, and its socioeconomic structure. Law is defining: it helps shape society, its values, and socioeconomic structure. Law is interpretive: it is the result of a dynamic process by which the perspectives of an interpreter and a text merge to yield an interpretation.

In part, the denial of neutrality/objectivity is also a prescriptive claim. ${ }^{117}$ Claims of neutrality are denials of normativity, the value choices that are inherent in law and social practice. If value choices are being made, it is best to recognize them as such. When you study the three opinions in Warshow - one mechanically formalist, one conservative legal process, one progressive legal process - you find them

116. The discussion in this paragraph is most influenced by: (1) feminism, see C. MACKINNON, FEMINISM UNMODIFIED (1987); Minow, supra note 55; (2) hermeneutics, see Eskridge, supra note 56; and (3) pragmatism, see Symposium on the Renaissance of Pragmatism in American Legal Thought, supra note 57; Patterson, Law's Practice (Book Review), 90 Colum. L. REV. 575 (1990).

117. For philosophical treatments of this denial, see R. BERNSTEIN, BEYOND OBJECTIVISM and Relativism: Science, Hermeneutics, aNd Praxis (1985); Peller, supra note 5, at 1191-259. 
essentially empty and disappointing. The debate between the majority and concurring opinions about the requirements of the necessity defense, and the debate between the concurring and dissenting opinions over whether or not the legislature had established a rule for decision, are equally sterile. Neither debate, and none of the opinions, addresses the significant moral and policy issues that are necessarily implicated in any decision on the merits: What would be the policy consequences, ex ante, of permitting the necessity defense in nuclear protest cases? Is it fair to use criminal sanctions as a restraint on speech about an important public issue? How real were the dangers posed by the Vermont Yankee reactor?

There is no way for the law to be "neutral" in this case. Recognizing this, the New Public Law challenges legal decisionmakers to justify their interventions on the merits. They cannot conceal their partisanship behind precedent, or empirical studies, or procedures. Under this ideology, moreover, law should be value-laden, because government is best conceived as the deliberation of an egalitarian citizenry seeking the public good. ${ }^{118}$ New Public Law tends to reject the heavy reliance of traditional theories upon jurisprudential positivism. It argues that the legitimacy of government rests primarily upon the values it represents, and not upon its procedural pedigree. ${ }^{119}$

\section{Law as Transformation, Preferences as Endogenous}

Unlike progressive legal process theory, New Public Law posits that law is more than facilitative (enabling interdependent humans to live together); it is both formative and transformative. Law can make

118. Thus, New Public Law is sympathetic to the claims of the "republican revival." Historians have argued the relevance of republican thought to the framing of the Constitution. See D. Epstein, The Political Theory of The Federalist (1984); J. Pocock, The MachiaVellian MOMENT 506-52 (1975); G. WOOD, The CREATION OF tHE AMERICAN Republic, 1776-1787 (1969); Appleby, Republicanism in Old and New Contexts, 43 WM. \& MARY Q. 20 (1986). Several New Public Law scholars view civic republicanism as an attractive normative framework for thinking about law and government. See Michelman, supra note 53; Sherry, supra note 53; Sunstein, supra note 53.

119. We think the celebrated thought-problem posed by J. SChUMPETER, CAPITALISM, SoCIALISM, AND DEMOCRACY 242 (1961), sets forth this position nicely:

Let us transport ourselves into a hypothetical country that, in a democratic way, practices the persecution of Christians, the burning of witches, and the slaughtering of Jews. We should certainly not approve of these practices on the ground that they have been decided on according to the rules of democratic procedure. But the crucial question is: would we approve of the democratic constitution itself that produced such results in preference to a non-democratic one that would avoid them?

Schumpeter answers the question in the negative, suggesting that a democratic government which did these things (by the way, not so far removed from apartheid, which sanctioned lynching, persecution, and segregation of African-Americans in the 1950s) was not legitimate. For modern legal variations on the theme that law's legitimacy depends upon its substance and not just its process, see R. DWORKIN, supra note 72, at 206-15 (contrasting "community of principle" as a more legitimate basis for social ordering than a "rulebook community"). 
us a "better" community, it can make us a "worse" community. Law is part of a web of sociopolitical structures that are constitutive - and reconstitutive - of our community.

New Public Law is skeptical of traditional pluralism and its assumptions. ${ }^{120}$ The key challenge is to the pluralist assumption that people's preferences in the political and legal process are exogenous, namely, that they are predetermined, independent of and prior to political activity. This assumption seems crazy to the generation whose members saw the civil rights debate transform people's beliefs about segregation and discrimination, whose antiwar protests toppled a president, and whose celebration of Earth Day changed the landscape of public policy. New Public Law scholars believe that people's preferences are endogenous to the political process. ${ }^{121}$ "Politics is a process ... for making the self-defining choices that constitute our moral freedom. . . . Such choices by their nature have to be made jointly, that is to say politically. Public values, then, are a necessary accompaniment of the moral freedom of the individual." 122

This idea relates to a conclusion drawn from law's normativity: law is responsible for doing something about the substantive ills of our society. Legal process theory essentially accepted the role of law as solving collective action and other problems brought to it by the private sector, partly because it accepted the idea that politics and law are a response to private preferences. Once it is accepted that people's preferences are inseparable from politics and law, law must accept some responsibility for social injustices and ought to gravitate toward transformation of the conditions generating the injustices and the attitudes tolerating them. Under this ideology, Warshow's failure to grapple with the intensely political issues posed by the case was irresponsible, and the majority's refusal even to let the jury discuss the issues looks antidemocratic. One can then see that the relatively responsible people in the case were John Warshow and the other defendants - "criminals" according to the legal process - for it is they who

120. Much of what follows is inspired by several interconnected intellectual movements, including (1) "civic republicanism," revived by historians to explain the political thought of the Framers, see supra note 116; (2) "communitarianism," which rejects liberalism's tendency to separate the individual from the community, see M. SANDEL, LIBERALISM AND THE LIMITS OF JUSTICE (1982); Regan, Community and Justice in Constitutional Theory, 1985 WIs. L. REv. 1073 ; and (3) developments in "liberal" political theory that point away from the extreme individualism of some variations. See Sunstein, supra note 53.

121. See Cover, supra note 54; Sunstein, Legal Interference with Private Preferences, 53 U. CHI. L. REV. 1129 (1986).

122. Michelman, Politics and Values or What's Really Wrong with Rationality Review?, 13 Creighton L. Rev. 487, 509 (1979). 
alerted the community to issues that were being swept under the table by the company, the regulators, and ultimately by the court.

\section{Law as Practical Reasoning}

Closely related to the normativity and formative/transformative nature of law is a third claim of New Public Law ideology. It is rather complicated and may profitably be broken into three interrelated assertions: law is politics, politics is the making of decisions that affect the community, and the dynamics of politics ought to be dialogic practical reasoning rather than coercive rule or rights enforcement.

The first two assertions are primarily descriptive and are more radical than they might seem at first, for they separate law from government. To be sure, government may be our most important source of law, because our communities spend substantial resources making decisions through government, typically in the form of statutes that are fleshed out by judicial and agency interpretations. But the law of such statutes is often determined in practice by lower level officials who implement them, by private lawyers who interpret them to their clients and others, and by lay people who are the statutes' ultimate audience. For example, the criminal trespass statute involved in Warshow probably does not prohibit any and all unpermitted entries onto Vermont Yankee's property. If a group of children entered the property, it is doubtful that Vermont Yankee would have called the police, and even more unlikely that the police would have arrested the children if they had been called. Indeed, if John Warshow had shown up at the plant alone and with a sign around his neck protesting the reactor's operation, it is not clear that Vermont Yankee would have complained. The plant and the authorities, of course, sprung into action when John Warshow showed up as part of a larger group seeking to keep the plant closed. All of these scenarios involve the creation of "law," and it can readily be seen that we cannot talk about "law" (even conventional statute-type law) without talking about the larger web of societal power relationships.

If law is a sociopolitical process of norm creation, it usually involves centers of sociopolitical power, including protest groups and homeowners and companies, as well as agencies and courts. We all know that the law created in such situations of power often favors elite status quo groups (the haves) - Vermont Yankee management and shareholders in Warshow - over the less wealthy (the have nots) the people living in Vernon, Vermont (the people who would be killed and contaminated if a meltdown occurred) and the environmental protesters. The haves in Warshow had the support of the police, the 
regulatory agency, and the court system, yet without any reason for us to believe that their operation of the power plant was safe and "lawful." The possibility is tangible that the haves won in Warshow because they were powerful.

As a normative matter, the New Public Law resists this. If law is politics, including social politics, the New Public Law rejects the pluralist vision of politics as deals struck on grounds of relative socioeconomic power. In its place, the New Public Law urges that the politics of norm creation constitutes a process of practical reasoning, and calls upon the "professional community to construct . . . an ongoing conversation about the pursuit of activist values in an incredibly complex world." 123 This ongoing conversation helps define the New Public Law's commitment to practical reasoning. In the spirit of the New Public Law, we turn to concrete examples of such practical reasoning, through a second case example and several representative law review articles.

\section{Law as Practical Reasoning}

To concretize what we mean by the New Public Law, and how it relates to themes of feminism, republicanism, pragmatism, and hermeneutics (in particular), we now turn to several articles that are distinctively "New Public Law" in their ideology and approach. And we apply the precepts of these articles to our second case example, Gay Rights Coalition of Georgetown University Law Center v. Georgetown University. ${ }^{124}$ Georgetown (where we both teach) is a Catholic university in Washington, D.C., and the Gay Rights Coalition is one of two groups of gay and lesbian students that sought university recognition in and after 1978. Reasoning that university recognition would imply approval of the gay and lesbian group, contrary to Catholic doctrine, Georgetown denied the Coalition's application. The Coalition sued Georgetown for damages and an injunction, arguing that Georgetown's refusal to recognize the student groups violated the District's Human Rights Act, which makes it "an unlawful discriminatory practice ... for an educational institution ... . [t]o deny, restrict or to abridge or condition the use of, or access to, any of its facilities and services to any person otherwise qualified, wholly or partially, for a discriminatory reason, based upon ... . sexual orientation . . .."125

The District's Court of Appeals held that the Human Rights Act

123. B. ACKERMAN, supra note 1 , at 20 .

124. 536 A.2d 1 (D.C. 1987).

125. D.C. CODE ANN. § 1-2520(1) (1981); see D.C. CODE ANN. §1-2501 (1981) (intent of D.C. Council "to secure an end in the District of Columbia to discrimination for any reason 
required Georgetown to provide the gay and lesbian student groups with equal access to funds and facilities but not to recognize the groups, and that as interpreted the statute did not violate Georgetown's first amendment right to the free exercise of religion. The opinion announcing the judgment of the seven-judge court was delivered by Judge Mack, ${ }^{126}$ with Judge Newman writing a concurring opinion differing in important respects from Judge Mack's opinion. ${ }^{127}$ Judges Ferren and Terry dissented from the court's holding that Georgetown University did not have to recognize the gay and lesbian groups, ${ }^{128}$ and Judges Nebeker and Belson dissented from the court's holding that the Act could constitutionally require Georgetown to provide equal access to gay and lesbian student groups. ${ }^{129}$

Unlike Warshow, the Case of the Gay Rights Coalition yielded a rich debate on the merits of Georgetown University's exclusion of gay and lesbian student groups. And whereas the dissenting opinion in Warshow was at most an exemplar of the "new" legal process, Judge Mack's opinion in Gay Rights Coalition is an early New Public Law exemplar, as is the partial dissent by Judge Ferren. Judge Mack's opinion first details the conflict between Georgetown University and the gay and lesbian students seeking to organize, ${ }^{130}$ then applies the Human Rights Act to the carefully delineated factual setting in light of the competing constitutional values, ${ }^{131}$ and finally evaluates the constitutionality of the Act as applied. ${ }^{132}$ In contrast to all the (formalist and legal process) opinions in Warshow and to the (formalist and legal process) opinions by Judges Nebeker and Newman in Gay Rights Coalition, Judge Mack's opinion is explicitly normative in its focus and evolution of the competing values involved in both statutory and constitutional interpretation; is antipluralist in its sensitivity to the values of two conflicting groups and in its efforts to transform the conflictual situation by an accommodationist compromise; and is contextual rather than abstract, engaged rather than neutral, and community-building rather than rights-oriented in its practical reason-

other than that of individual merit, including, but not limited to, discrimination by reason of ... sexual orientation"); D.C. CODE ANN. § 1-2502(28) (1981) (defining "sexual orientation").

126. Gay Rights Coalition, 536 A.2d at 5 (Mack, J., delivering the judgment of the court). Chief Judge Pryor essentially joined her opinion. 536 A.2d at 39 (Pryor, C.J., concurring).

127. 536 A.2d at 40 (Newman, J., concurring).

128. 536 A.2d at 46 (Ferren, J., concurring in the result in part and dissenting in part); 536 A.2d at 74 (Terry, J., concurring in part and dissenting in part).

129. $536 \mathrm{~A} .2 \mathrm{i}$ at 62 (Belson, J., concurring in part and dissenting in part); $526 \mathrm{~A} .2 \mathrm{~d}$ at 75 (Nebeker, $j$., concurring in part and dissenting in part).

130. 536 A.2d at 5-14 (opinion of Mack, J.).

131. 536 A.2d at $16-30$.

132. 536 A.2d at 30-39. 
ing. In the way it "does law," Judge Mack's opinion parallels recent New Public Law scholarship. We use this scholarship to deepen our analysis of her opinion.

\section{Public Values in Statutory Interpretation}

A distinctively New Public Law scholarship is emerging in the field of statutory interpretation. ${ }^{133}$ Deeply influenced by republicanism, hermeneutics, and pragmatic philosophy, New Public Law scholarship goes well beyond the progressive legal process position that interpretation is dynamic and must carry out the statute's purposes over time. Applying republican ideals, New Public Law scholars tend to criticize traditional approaches to statutory interpretation (textualism, intentionalism, purposivism) as indeterminate and naive. ${ }^{134}$ They argue that statutory interpretation is decisively influenced by background assumptions and values, often controversial, held by the interpreter; ${ }^{135}$ and endorse the importance of these assumptions (usually expressed as presumptions, clear statement rules, and canons of statutory interpretation) if and only if they are updated to reflect the economic and social needs of the modern regulatory state. ${ }^{136}$ The practical reasoning urged by New Public Law scholars is illustrated by several features of Judge Mack's opinion in Gay Rights Coalition, namely, (1) its explicit invocation of background norms in doing statutory interpretation, (2) its critical evaluative stance toward the legislative materials, and (3) its careful treatment of colliding norms.

The lower court in Gay Rights Coalition had applied the statutory "plain meaning" (so popular in the 1980s) to require Georgetown University to recognize the gay and lesbian student groups and then declared the Act an unconstitutional abridgement of first amendment rights. New Public Law scholars are highly critical of the naive form of the plain meaning approach, because it wrongly denies the dependence of text upon "both culture and context," especially background

133. See Aleinikoff, supra note 64; Eskridge \& Frickey, Statutory Interpretation as Practical Reasoning, 42 STAN. L. REv. 321 (1990); Mootz, The Ontological Basis of Legal Hermeneutics: A Proposed Model of Inquiry Based on the Work of Gadamer, Habermas, and Ricoeur, 68 B.U. L. REv. 523 (1988); Patterson, Wittgenstein and the Code: A Theory of Good Faith Performance and Enforcement Under Article Nine, 137 U. PA. L. Rev. 335 (1988); Sullivan, The Supreme Court, 1985 Term - Comment: Sins of Discrimination: Last Term's Affirmative Action Cases, 100 HARv. L. REv. 78 (1986); Sunstein, supra note 61; Zeppos, supra note 64. See generally Schanck, The Only Game in Town: An Introduction to Interpretive Theory, Statutory Construction, and Legislative Histories, 38 KAN. L. REv. 815 (1990).

134. Eskridge, Public Values in Statutory Interpretation, 137 U. PA. L. REv. 1007 (1989); Sunstein, Interpreting Statutes in the Regulatory State, 103 HARV. L. REV. 405 (1989).

135. Eskridge, supra note 134, at 1019-61; Sunstein, supra note 134, at 420-62.

136. Eskridge, supra note 134, at 1073-92; Sunstein, supra note 134, at $462-503$. 
norms. ${ }^{137}$ Judge Mack does not start with the statutory plain meaning. Instead, she starts with an explicit consideration of the constitutional norms as background assumptions for the interpretive enterprise. ${ }^{138}$ Invoking the traditional canon that statutes should be interpreted to avoid constitutional problems, Judge Mack explores Georgetown's argument that allowing gay and lesbian groups on campus would threaten the university's Catholic traditions. She then turns to a careful examination of the record, from which she draws the conclusion that Georgetown's main difficulty was with a requirement that it "endorse" gay and lesbian student groups, which could be disaggregated from tangible benefits implicated in requiring equal "access" of gay and lesbian student groups to university facilities. ${ }^{139}$ Only in the context of these facts and of the constitutional norms does Judge Mack, finally, return to the statutory text, which she finds receptive to the interpretation that Georgetown must provide equal access to "facilities and services" but need not provide an official endorsement. ${ }^{140}$ What is most impressive about Judge Mack's opinion is its open acknowledgement that statutory text must be interpreted against the background of other norms and the facts of the case.

Another feature of New Public Law practical reasoning, as developed in these articles, is its relentlessly critical stance toward statutory materials. Their emphasis is examination and not deference. ${ }^{141}$ Just as Judge Mack's opinion refreshingly avoids formalist cant about "plain meaning," it also avoids reasonless "deference" to made-up "legislative intent." For example, when Judge Mack analyzes Georgetown's argument that the Human Rights Act as interpreted violates the free exercise of religion, her opinion digs through the Act's (unpublished) legislative history to demonstrate the District's "compelling interest" in ending discrimination against gay men and lesbians ${ }^{142}$ but refuses to stop with the lessons of the legislative history. Over the objections of one of her concurring brethren that the court defer to the

137. Sunstein, supra note 134, at 416; see id. at 415-24; Eskridge, supra note 134, at 1018-29; Eskridge, The New Textualism, 37 UCLA L. REv. 621 (1990).

138. Gay Rights Coalition, 536 A.2d at 16 (opinion of Mack, J.); see 536 A.2d at 21-36 (examining constitutional values). This precept of statutory interpretation is a key "canon" in Eskridge, supra note 134, at 1020-22 (analysis of this canon); Sunstein, supra note 134, at 468-69.

139. 536 A.2d at $16-20$.

140. 536 A.2d at 21-30.

141. Eskridge, supra note 134, at 1063-73, 1085-86; Sunstein, supra note 134, at 444-46; see Eskridge \& Ferejohn, Making the Deal Stick: Enforcing the Original Understanding in the Modern Regulatory State, J.L. ECON. \& ORG. (forthcoming 1991); Sunstein, Law and Administration After Chevron, 90 Colum. L. Rev. 2071 (1990).

142. 536 A.2d at $31-33$ (opinion of Mack, J.). 
well-deliberated legislative judgment, ${ }^{143}$ Judge Mack subjects the antidiscrimination policy to independent normative examination. Her history and evaluation of the treatment of gay men and lesbians in this country leads her to conclude that not only were there compelling policy reasons behind the District's law, but also that constitutional concerns favoring equal treatment of gay men and lesbians further buttressed the District's compelling interest in ending discrimination against gay men and lesbians. Although not blindly deferring to the legislative materials, Judge Mack's opinion is exemplary in its careful attention to the precise values the legislature was trying to protect (her exhaustive analysis of the legislative history) and in its critical approach to those values (her scrutiny of the legislature's reasons for protecting gay men and lesbians against discrimination). On the other hand, Judge Mack's opinion fails to subject Georgetown's values (the Catholic Church's rejection of homosexuality) to the same critical scrutiny. ${ }^{144}$

Finally, and not least, Judge Mack's opinion confronts the problem of colliding and conflicting norms, a problem highlighted but not "solved" in New Public Law articles. ${ }^{145}$ Two judges dissented from her constitutional concerns that Georgetown not be compelled to "endorse" an organization repugnant to its religious principles, ${ }^{146}$ and two other judges dissented from her failure to press Georgetown's free exercise claim against providing facilities for such an organization. ${ }^{147}$ Judge Mack deals with these colliding norms through a critical analysis of their traditions and a careful attention to how much each would be compromised by different interpretations. Interpreting the Human Rights Act to compel Georgetown, a Catholic university, to "endorse" student groups of which it disapproves, would go to the crux of the school's religious orientation and implicates freedom of speech concerns as well. ${ }^{148}$ This is met by Judge Ferren's argument that university "recognition" of gay and lesbian student groups is not the same as

143. 536 A.2d at 42 (Newman, J., concurring).

144. 536 A.2d at 36 (opinion of Mack, J.); see 536 A.2d at 33-38. In this regard, Judge Ferren's partially dissenting opinion is a better example of New Public Law. 536 A.2d at 46-62 (Ferren, J., concurring in the result in part and dissenting in part). But even Judge Ferren's opinion fails to grapple with the complex substantive issue of the reasons why the Catholic Church disapproves of homosexuality. See J. Boswell, Christianity, Social Tolerance, and homosexuality: Gay People in Western Europe from the BeginNing of the Christian ERA to the Fourteenth Century (1980).

145. Eskridge, supra note 134, at 1073-91; Sunstein, supra note 134, at 497-502.

146. 536 A.2d at 49-54 (Ferren, J., concurring in the result in part and dissenting in part). We find the views expressed by Judge Ferren to be quite attractive on the merits.

147. 536 A.2d at 67-74 (Belson, J., concurring in part and dissenting in part).

148. 536 A.2d at 21-26 (opinion of Mack, J.). 
university "endorsement" of their views. ${ }^{149}$ Judge Mack responds that Georgetown views recognition as endorsement, and that compelled recognition is a more direct attack on Georgetown's religious mission than requiring access to facilities, with less of a need by the student groups for such recognition. ${ }^{150}$ On the other hand, interpreting the Human Rights Act to compel Georgetown to provide gay and lesbian groups with access to facilities and benefits provides these groups with tangible means to assert their identities and views, while presenting a less direct affront to the university's religious mission.

\section{Colliding Norms in Public Law}

Probably the most difficult problem in public law is how to deal with conflicting and colliding norms. The constitutional issue in Gay Rights Coalition is whether Judge Mack's interpretation of the statute unconstitutionally burdens Georgetown's free exercise of religion. As her opinion makes clear, that pits free exercise norms pressed by Georgetown against the antidiscrimination norm pressed by the gay and lesbian students. ${ }^{151}$ A major challenge faced by the New Public Law is to develop practical reasoning for dealing with colliding norms. The traditions of hermeneutics and republicanism confront this challenge, as does an emerging New Public Law literature drawing from feminism ${ }^{152}$ and pragmatism. ${ }^{153}$

Two articles in this genre are Suzanna Sherry's "Civic Virtue and the Feminine Voice in Constitutional Adjudication"154 and Margaret Jane Radin's "The Pragmatist and the Feminist."155 Applying insights from feminist theory and (in Radin's article) complementary

149. 536 A.2d at 51-52 (Ferren, J., concurring in the result in part and dissenting in part). Judge Ferren also engages in an interesting battle of analogies with Judge Mack. He argues that her interpretation creates a "separate but equal" regime of student organizations at Georgetown that would be objectionable if applied to racial groups, obviously invoking the negative example of Plessy. 536 A.2d at 49-50. Judge Mack argues that his interpretation would cut off the ability of a Gay University of America to create a community of interpretation. 536 A.2d at 25-26 (opinion of Mack, J.).

150. 536 A.2d at 19-20 (opinion of Mack, J.). But see 536 A.2d at 52 n.9 (Ferren, J., concurring in the result in part and dissenting in part).

151. 536 A.2d at 30-38 (opinion of Mack, J.).

152. See, e.g., C. MACKInNon, supra note 55; Minow, supra note 55; West, Feminism, Critical Social Theory and Law, 1989 U. CHI. LEGAL F. 59.

153. See, e.g., Eskridge \& Frickey, supra note 15; Farber, Legal Pragmatism and the Constitution, 72 MinN. L. Rev. 1331 (1988); Grey, Holmes and Legal Pragmatism, 41 STAN. L. Rev. 787 (1989); Patterson, supra note 116; Radin, Reconsidering the Rule of Law, 69 B.U. L. REV. 781 (1989); Singer, Should Lawyers Care About Philosophy? (Book Review), 1989 DukE L.J. 1752; Shreve, Symmetries of Access in Civil Rights Litigation: Politics, Pragmatism and Will, 66 IND. L.J. 1 (1990).

154. Sherry, supra note 53.

155. Radin, The Pragmatist and the Feminist, 63 S. CAL. L. REv. 1699 (1990). 
insights from pragmatist theory, these articles argue a commitment toward legal decisionmaking that emphasizes situatedness and context instead of universals and abstractions; reconciliation and accommodation instead of conflict and rights; and community instead of autonomy. ${ }^{156}$ The perspective suggested by Sherry and Radin is important to Judge Mack's opinion and to her treatment of colliding norms, and Sherry (at least) would find it significant that Judge Mack is a woman (the only woman on the seven-judge bench). Their perspective suggests several features to Judge Mack's practical resolution of colliding norms, namely, (1) its focus on group needs and interests rather than individual rights, (2) its sensitivity to the voice of the dispossessed, and (3) its effort to reconcile rather than to separate.

Sherry outlines a feminist jurisprudential framework that illuminates the contrast between Judge Mack's approach and that of her colleagues. ${ }^{157}$ Traditional, male-oriented Anglo-American jurisprudence has assumed the primacy of atomistic individuals whose autonomy is protected by the enforcement of constitutional "rights," either through transcendental bright-line rules or utilitarian balancing tests. Sherry contrasts traditional jurisprudence with that of the republican tradition, and with that suggested by modern feminist scholarship. Feminist jurisprudence starts with the primacy of the community and of groups within the larger community, and situates individuals not as autonomous but as connected with one another, and with a variety of communities. This perspective more readily recognizes constitutional disputes as an opportunity to deal with norms in collision. Constitutional decisionmaking therefore is not rule-based, rights-based, or utilitarian balancing. It is not abstract, neutral, or hierarchal - it is instead concrete and situated, engaged, and web-like. ${ }^{158}$

The Gay Rights Coalition opinions reveal a virtually complete array of approaches to constitutional adjudication. The dissenting judges all speak in the argot of "rights" and "balancing" of those rights (as oxymoronic as this sounds). In contrast, Judge Mack focuses on community and group needs and interests, as reflected in the language of her opinion: rather than speaking of the "violation" of Georgetown's free exercise "rights," as her dissenting brethren do, 159

156. Id. at 1707 (similarities of feminism and pragmatism); Sherry, supra note 53, at 580-91 (similarities of feminism and republicanism).

157. Sherry, supra note 53, at 548-49, 582; see id. at 542-613 (applying framework to Justice O'Connor's early record).

158. Radin, supra note 155 , at 1712-19, however, cautions against overgeneralization.

159. Gay Rights Coalition, 536 A.2d at 67-74 (Belson, J., concurring in part and dissenting in part) (repeated focus on Georgetown's "rights," the terribleness of community "compulsion"); 526 A.2d at 75 (Nebeker, J., concurring in part and dissenting in part) (similar). 
Judge Mack discusses the "burden ... on Georgetown's religious exercise," and the "interest" of the larger community in eliminating discrimination on the basis of sexual orientation. 160

In treating the colliding norms - the free exercise burden and the antidiscrimination policy - Judge Mack's opinion contrasts with both her concurring and dissenting brethren. In analyzing the District's antidiscrimination interest, Judge Mack not only examines the legislative materials, but subjects them to historicist scrutiny which strengthens the public need for the District's effort to eliminate discrimination on the basis of sexual orientation. ${ }^{161}$ In effect, what she does is expand upon the legislative history to incorporate information about the nonvolitional nature of homosexuality, the vicious persecution of gay men and lesbians, and the ways in which that persecution demeans the community. Strikingly, this analysis draws disagreement from concurring Judge Newman. He argues for simple deference to the District's stated policy of nondiscrimination, based upon the traditional legal process notion that courts cannot sit as "super-legislatures to divine the importance of governmental interests,"162 and must instead hue to "what are surely the main qualities of law, its generality and its neutrality." "163 Under Sherry's analysis, these traditional male-oriented qualities of deference and hierarchy, generality and neutrality, might be usefully abandoned for an approach that is openly engaged and normative, concrete and political.

The dissenting judges sharply disagree with Judge Mack's willingness to consider protection of gay men and lesbians as a truly compelling governmental interest. Indeed, dissenting Judge Nebeker finds that "no factor favoring a state interest under the Act which can be balanced against Georgetown's rights," because the "conduct inherent in homosexual 'life-style' is felonious" and entitled to no weight in the constitutional balance. ${ }^{164}$ To make his point, Judge Nebeker attaches three pictorial examples of "propaganda used to announce dances and gatherings" among gay and lesbian students at George Washington University. ${ }^{165}$

Radin's article helps explain the striking differences among Judges Mack, Newman, and Nebeker on the issue of how to treat the interests of gay men and lesbians. Radin criticizes traditional jurisprudence for

160. 536 A.2d at 30-39 (opinion of Mack, J.).

161. 536 A.2d at 31-38.

162. 536 A.2d at 41 (Newman, J., concurring).

163. $536 \mathrm{~A} .2 \mathrm{~d}$ at 43 (quoting Wechsler, supra note 2, at 16).

164. $536 \mathrm{~A} .2 \mathrm{~d}$ at 75 (Nebeker, J., concurring in part and dissenting in part).

165. 536 A.2d at 75-78. 
its complacency and its failure to understand "the perspective of the oppressed."166 In part because women have directly experienced social domination and false consciousness, feminist thought has been unusually sensitive to the perspective of the oppressed. In contrast to Judge Nebeker, who writes from the perspective of traditional prejudice, and Judge Newman, who writes from the perspective of a status quo-oriented legal process, Judge Mack, a woman, makes an eloquent case for treating gay men and lesbians with equal respect, and for criticizing discrimination against them. Radin's article suggests that Judge Mack's extensive analysis of homosexuality in a heterosexual world is an effort to liberate us from a false consciousness.

A final feminist theme important to New Public Law practical reasoning is that of approaching conflicts from a different angle, and seeking reconciliation rather than just adopting a win/lose posture. ${ }^{167}$ Although many feminist scholars such as Radin do not believe that women inherently approach problem-solving in a completely different way from men, ${ }^{168}$ this theme may provide insight into Judge Mack's opinion. The parties posed the issues in the lawsuit in starkly dichotomous, win/lose terms: either Georgetown was required to recognize the gay and lesbian student groups or it was not. This posing of the issue sharpened the conflict between the norms in the case. Over the strong objection of some of her colleagues, ${ }^{169}$ Judge Mack refused to look at the issue in this simple way, and bifurcated the issue into a recognition/endorsement feature and an access-to-facilities feature. Analytically, this move enabled Judge Mack to save the Human Rights Act from serious constitutional difficulty, while still giving effect to its core policy. Practically, this move enabled Judge Mack to offer a result that accommodated the most significant needs of both groups: The gay and lesbian student groups received access to facilities and benefits needed to provide support for students, and Georgetown was able to preserve its integrity as a Catholic institution.

\section{Reconciliation, Freedom, and Community}

New Public Law practical reasoning draws from hermeneutics, republicanism, feminism, and pragmatism, as developed above. We have seen how Gay Rights Coalition involves normative decisionmak-

166. Radin, supra note 155, at 1711; see also Brewer, Pragmatism, Oppression and the Flight to Substance, 63 S. CAL. L. REv. 1753 (1990).

167. This is a theme of Carol Gilligan, C. Gilligan, IN A Different Voice: PsychologICAL THEORY AND WOMEN'S DEVELOPMENT (1982).

168. Radin, supra note 155, at 1712-19.

169. Gay Rights Coalition, 536 A.2d at 48 (Ferren, J., concurring in part and dissenting in part); 536 A.2d at 62-63 (Belson, J., concurring in part and dissenting in part). 
ing in its statutory as much as its constitutional interpretation, and how the New Public Law might treat the colliding norms in that case - seeking accommodation and reconciliation instead of creating a sharp win/lose hierarchy. What remains is to connect this project with a political/constitutional theory of judging. That has been the work of Frank Michelman, whose articles on "Traces of Self-Government" 170 and "Law's Republic" 171 relate themes from republicanism, feminism, critical race theory, gay-law, law and religion, hermeneutics, and pragmatism to a political theory outlining the role of the judge.

Like the late Robert Cover, whom he invokes, Michelman laments the "jurispathic" role of authoritarian judging, exemplified by the dissenting opinions in Gay Rights Coalition. ${ }^{172}$ At least two different communities of interpretation were on a collision course in that case - Georgetown University, whose Catholic tradition morally disapproves of homosexual relations, and the gay and lesbian student groups, which were part of a larger struggle to transform traditional oppression of gay men and lesbians. The parties to the lawsuit, and most of the judges, saw the case in traditional terms, in which the court would "kill" the position of one side or the other by choosing its interpretation of the "law." Judge Nebeker, most starkly, was committed to suppressing the gay and lesbian community, in a violent and assaultive dissenting opinion. ${ }^{173}$ Though far less assaultive, Judge Ferren's opinion argued strongly for overriding all of Georgetown's free exercise claims, subordinating them entirely to the claims of the gay and lesbian student groups. ${ }^{174}$ Both of these judges saw their role as jurispathic - killing the genuine needs of a vibrant (but to each objectionable) community of interpretation, under the aegis of "law's empire." 175

Michelman argues against authoritarian judging, because it exacerbates the tension between our constitutional ideals of self-government and government of laws. ${ }^{176}$ By taking an imperial stance that exercises a nonmajoritarian dominion over one of the two communities, the authoritarian judge is denying freedom to one of the communities

170. Michelman, supra note 53.

171. Michelman, Law's Republic, 97 YALE L.J. 1493 (1988).

172. Michelman, supra note 53, at 133 (invoking Cover, supra note 54.

173. Gay Rights Coalition, 536 A.2d at 75-78 (Nebeker, J., concurring in part and dissenting in part) (according no legal interest in protecting gay men and lesbians and branding all homosexuals as "criminal[s]").

174. 536 A.2d at $46-62$.

175. See Michelman, supra note 53, at 66-73.

176. Michelman, supra note 171. 
to set its own norms, and thereby abridging that community's citizenship, its part in self-government. 177 Given the assumptions of our pluralism, authoritarian judging and law's empire will undermine selfgovernance. Set against this vision is Michelman's vision of "law's republic," in which the judge's role is "jurisgenerative" (Cover's term) - offering reconciliation and opportunities for a "dissolution of difference" between clashing communities. ${ }^{178}$ Only by redefining the problem or offering opportunities for the transformation of preferences, or both, can the judge - and our polity - protect the self-government and citizenship of the communities. This is true government of laws.

As Michelman puts it, "certain characteristic themes" bind together the "reconciliatory project." In his words:

The dialogic themes express the vision of social normative choice as participatory, exploratory, and persuasive, rather than specialized, deductive, or demonstrative. They emphasize openness to "otherness" as a way toward recognition not only of the other but also of oneself.

The historical themes express the sense that the conversation neither begins nor ends now. We have individual pasts and a collective past, and those pasts raise for us issues of identity and integrity. At the same time we have, we hope, our individual and collective futures, and our conversation now ought not to foreclose future conversations.

The responsibility themes express demands for both clear-sightedness and personal engagement. They warn against the comforts of legal abstraction, hiding or overlooking actualities of social disadvantage. They protest against projection of the agency of decision onto a distant force - such as law or state - when the truth is that their distance is what we make it by our deference.

The identity themes reflect the tug between the demands for both ethical situation and personal "space" as dual conditions of freedom. They also point most obviously towards the irresolvable tension between generality and particularity that pervades the reconciliatory enterprise as a whole. 179

Judge Mack's opinion in Gay Rights Coalition takes seriously the responsibility of the judge to be open to perspectives of others, particularly those who have been excluded from citizenship.

Michelman's articles suggest an explanation and justification for Judge Mack's "compromise" decision. It was an overture for the parties to join in a modus vivendi, a shared community that over time

177. Thus, Judges Nebeker and Belson undermine the freedom of the gay and lesbian students, 536 A.2d at 62-78, and Judges Ferren and Terry undermine the freedom of Georgetown University. 536 A. $2 d$ at 46-62. Judge Newman under this analysis tends to deny self-governance of both groups in his deferential refusal to examine the norms chosen by the legislature. 536 A.2d at $40-46$.

178. Michelman, supra note 171, at 1526-27; Michelman, supra note 53, at 31-33.

179. Michelman, supra note 53, at 33 (emphasis added) (footnotes omitted). 
could ameliorate their normative differences in ways that a judicial decree cannot. As compromises often do, this was immediately disappointing to both parties; but in the longer term this is not necessarily the case. As law professors at Georgetown University Law Center, we think that the university community is better off because of the activities of the gay and lesbian student groups, and that the University itself has a more productive approach to gay and lesbian students because of its relationship with these groups. One of us (Eskridge) is also an adviser to the gay and lesbian student group at the Law Center, and believes that gay and lesbian students are less alienated from the educational experience because of the more constructive approach taken by the University, and that the gay and lesbian student group has become an important part of the academic community. To that extent, Judge Mack's compromise has been a jurisgenerative experience. On the other hand, the compromise has left gay and lesbian student groups as the only ones which must publicly (and repeatedly) present themselves as not reflecting the values of Georgetown University. To that extent, Judge Mack's compromise has left the gay and lesbian groups permanently stigmatized.

\section{The New Public Law and the Politics of Legal SCHOLARSHIP}

The New Public Law encompasses particular aspects of a changing conception of dominant American legal institutions. We have grouped together the recent work of Frank Michelman, Harold McDougall, Cass Sunstein, William Eskridge, Daniel Farber, Philip Frickey, Suzanna Sherry, Martha Minow, Ed Rubin, Cynthia Farina, and others. We sense that there is something similar about the move to "republicanism" in constitutional interpretation, the embrace of "public values" and "hermeneutics" in statutory interpretation, the insistence on stricter judicial review of administrative action, the reconceptualization of the law/politics and reason/passion distinctions in terms of law's "practical reason," the embrace of a particular form of feminist thought, and the assertion of "perspectivalism" and the commitment to cultural "diversity" in political theory. It is not that all of these aspects of recent scholarship are necessarily linked through a shared adherence to a set of philosophical premises. Instead, this work constitutes a genre of legal thought. The body of work hangs together like an artistic style might, even though each manifestation might be very different. The shared attributes are tonal and attitudinal; they appear as pieces of a general cultural turn in our intellectual 
context recognizable largely for not being something else, such as law and economics or CLS.

This article has taken as its main project the depiction of the New Public Law as a genre of legal scholarship. In the first two Parts, we related the work to the dominant discourse of American legal theory for the past thirty years, the legal process synthesis of the 1950s. The New Public Law scholarship both continues and dramatically reforms the legal process approach.

The recent public law work shares with the legal process tradition the central idea that justice resides in process - that legal analysis should describe particular procedures for reaching decisions about the terms of social life. Thus the scholarship focuses on deliberation, practical reason, regulatory failure, factionalism, and dialogue. To put this another way, the agenda continues to be set by the intellectual taxonomy of the legal process approach: the central question is whether the process of decisionmaking has been legitimate. For example, part of the rhetorical force of Frank Michelman's "Traces" article $^{180}$ lies in the use of Justice O'Connor's opinion as the exemplar of decisionmaking, even though it is obvious that Michelman and Justice O'Connor have deep ideological differences. Procedure is thus separate from politics; the mode of engagement, contextualization, and responsibility that Michelman encourages in Justice O'Connor's approach can legitimate an exercise of power separate from its substantive ideology.

But this new generation of scholars has also reformed the legal process synthesis through a new emphasis on what we have called "normativity." We use this term to refer to a conviction that no issues are simply "procedural," and thus no institution may ever simply defer to the substantive decisions of another institution. There is some real tension between these two aspects of the New Public Law scholarship; the direction of reform seems to undermine the basic, historical justification for the adoption of the legal process analytic itself. If we are right that the turn to proceduralism was at least in part occasioned by the corrosive legal realist attack on the intellectual coherence of a neutral and objective regime of substantive law, ${ }^{181}$ then it is at first glance odd that New Public Law scholars would preserve the focus on process within a practice that proclaims itself openly normative.

In this Part, we address the tension we see within the New Public Law scholarship - between an attraction to proceduralism and never-

180. See supra notes $170-179$ and accompanying text.

181. See supra notes $36-41$ and accompanying text. 
theless a conviction that all decisionmaking is ultimately normative by situating the movement in the ideological and intellectual context of legal scholarship in the 1980s. In addition to comparing this new work to the legal process tradition, it is also important to see the New Public Law scholarship as a reaction to the politicization of legal scholarship that began in the late 1970s and that was overt by the 1980s. This period included the rise of an explicitly leftist CLS movement, ${ }^{182}$ the development of right-wing and moderate versions of law and economics, ${ }^{183}$ the founding of a feminist legal movement with its own liberal and radical factions, ${ }^{184}$ and, by the end of the 1980 s, the organízation of a distinctly left-leaning cadre of scholars of color. ${ }^{185}$ And all this occurred in the context of the simultaneous disintegration of an intellectual or ideological "center," of some perspective that could claim to be the position of the "true professionals," and against which all these other factions would appear deviant. ${ }^{186}$

We believe that New Public Law scholars are constructing their discourse in part in the desire to resolve the sense of conflict and disintegration in legal academic culture. These scholars aim to articulate a new consensus position that could take account of the "partial truths" of the extant intellectual factions while transcending them all in favor of a new synthesis. Ironically, in this dimension, the New Public Law scholarship is similar to the legal process thinkers of the 1950s; both

182. For various accounts, see M. KelmaN, A Guide to CRITICAI LEgal StUdies (1987); R. Unger, The Critical Legal Studies Movement (1986); Boyle, The Politics of Reason: Critical Legal Studies and Local Social Thought, 133 U. PA. L. REv. 685 (1985); Note, 'Round and Round the Bramble Bush: From Legal Realism to Critical Legal Scholarship, 95 HARv. L. ReV. 1669 (1983). For collections of CLS essays, see CRITICAL LEGAL STUDIES (A. Hutchinson ed. 1989); THE PolmTics of LaW, supra note 5; Critical Legal Studies Symposium, 36 STAN. L. Rev. (1984); A Symposium of Critical Legal Studies, 34 AM. U. L. Rev. (1985).

183. See R. Posner, The Economic Analysis of LAW, supra note 49; G. Calabresi, supra note 49; A. POLINSKY, INTRODuction to LAW AND ECONOMICS (1983); C. GoETZ, LAW AND ECONOMICS (1984).

184. See C. MacKinnon, supra note 116; Dalton, An Essay in the Deconstruction of Contract Doctrine, 94 YALE L.J. 997 (1985); Olsen, The Family and the Market, 96 HARV. L. REV. 1497 (1983); Williams, Equality's Riddle: Pregnancy and the Equal Treatment/Special Treatment Debate, 13 N.Y.U. REv. L. \& SoC. ChANGE 325 (1984-85).

185. See D. Bell, AND We ARE Nor SAved (1987); Minority Critiques of the Critical Legal Studies Movement, 22 HARV. C.R.-C.L. L. REv. 297 (1987) (series of articles); Cook, supra note 54; Crenshaw, Race, Reform and Retrenchment: Transformations and Legitimations in Antidiscrimination Law, 101 HaRv. L. Rev. 1331 (1988); Matsuda, Public Response to Racist Speech: Considering the Victim's Story, 87 Mich. L. REv. 2320 (1989); Torres \& Milun, Translating Yonnondio by Precedent and Evidence: The Mashpee Indian Case, 1990 Duke L.J. 625; Williams, The Obliging Shell: An Informal Essay on Formal Equal Opportunity, 87 MICH. L. REv. 2128 (1989).

186. For a short time, it seemed that an updated legal process analytic - updated to account for Brown v. Board Of Education, 347 U.S. 483 (1954), and issues of racial, gender and sexual justice - could play this role, or that some ACLU-type rights discourse would become the default position for defining reasonableness in legal scholarship. That has not occurred. 
embody the attempt to mediate the ideological polarization of legal discourse. We conclude this section with the observation that the New Public Law is one manifestation of a cultural current in American life that can best be understood as a reaction of "centrism," a desire to avoid conflict and difference by locating a position between perceived "extremes."

One aspect of our view of the New Public Law as a centrist mediation derives from the sense that much of the New Public Law genre resonates with ideas and intellectual perspectives that, very recently, were considered "radical" and were associated almost exclusively with the work of the Conference on Critical Legal Studies. Although within the New Public Law group there are roughly identifiable conservative and liberal ideological groups, the movement as a whole has a progressive tone. If we are right that the New Public Law constitutes a new center for legal scholarship, it is nevertheless well to the left of what had been the center for previous generations of legal academics. One aspect of this is the embrace of Brown and the ideals of racial and gender justice as fundamental to the view of law. Another is the extent to which opposition to the law-and-economics movement establishes common intellectual ground with leftist intellectuals who have most fully engaged and criticized the reigning economic approaches to law.

In this section, we explicate the congruence between many ideas of the New Public Law scholarship and CLS work, which underlie the sense of a left tilt to the New Public Law scholarship. Both can be understood as movements putting at the center of their intellectual agenda a critique of positivism.

Part of the reason that the New Public Law scholarship sounds tilted to the left lies in its self-conscious adoption of the critique of positivism that is similar to the critique CLS writers have often adopted and arguably in turn appropriated from critical realist work. But we also believe that the critique of positivism has meant different things for different intellectuals - those adopting antipositivism need not embrace an oppositionist view of social relations. Indeed, the New Public Law scholars deradicalize the left's intellectual discourse even as they embrace it. Part of understanding the New Public Law as a centrist movement involves comprehending the political transformation that radical ideas about interpretative indeterminacy and the social construction of reality have undergone recently as they have been utilized by a new scholarly genre. 


\section{A. Intellectual Politics and the Issue of Positivism}

One way of approaching twentieth-century American legal thought is to see it as a series of conflicts over the possibility of an objective, determinate representation of social events - as intellectual skirmishes between positivist and antipositivist ideologies. We use "antipositivist" to suggest that the key jurisprudential conflict is not organized around the poles of positivism and natural law, as conventionally conceived. ${ }^{187}$ Rather, the key conflict is between positivism and the assertion of the inevitability of interpretation - that is, the "indeterminacy" position. From this viewpoint, positivist and natural law jurisprudences do not stand as opposites, but rather share the characteristic of being "objectivist"188 or, in Richard Rorty's terms, "foundationalist."189 In our terms, they are both instances of a more general form of positivism, understood as an interpretative mode that poses a qualitative dichotomy between the act of interpretation and the object of interpretation. Such a mode must assume the interpretative act can be governed by and checked against the positive content of some objective reality that exists separate from the interpretation itself. ${ }^{190}$ What makes the New Public Law actually new, compared to the legal process tradition, is that New Public Law scholars have made antipositivism central to their epistemological, methodological, and substantive positions. This antipositivism also characterizes much of the work of CLS, leading to our conclusion that, in terms of intellectual positions, CLS and at least the progressive wing of New Public Law share a great deal of ground. 191

187. Morton Horwitz suggests that the incessant understanding of American jurisprudential conflict as dividing around positivism and natural law may be due to a certain winner's history, through which the realists' false claims that the sins of the liberty of contract era were based on their adoption of natural law have since been adopted in mainstream discourse. Horwitz, Republicanism and Liberalism in American Constitutional Thought, 29 WM. \& MARY L. REV. 57, 7374 (1987).

188. R. UNGER, supra note 182 , at 3.

189. R. RORTY, Philosophy aNd the Mirror of NAtURe (1979).

190. The key here is to grasp that the "objective reality" can be either the traditional "empirical facts" of positivism in its modern, scientific dimension, or the a priori possibilities of reflection and contemplation in the natural law tradition. See Peller, supra note 5, at 1160-76 (linking theories of determinate representations as elements of a generalized metaphysics of presence, or of "positivism").

191. As we evaluate New Public Law scholarship here, what separates it from the legal process tradition is the rejection of liberal images of representation as an objective process. We believe that divisions within the body of New Public Law work can be understood on the same axis - more progressive, left-leaning work, like that of Frank Michelman, see supra notes 170-79 and accompanying text, is marked by the tendency toward more and more thoroughgoing antipositivist premises. In contrast, the conservative wing of New Public Law, say, the work of Jonathan Macey, see supra note 85, tends to employ positivist methodologies like public choice theory, albeit within the umbrella of New Public Law because they are in service of a critique of structural problems of institutional decisionmaking. 
As we see it, the issue of positivism has served as an ideological marker to divide progressive and conservative intellectual approaches, both in legal thought and in intellectual life generally. Although this structure of associations is not predetermined, it is as if, in the intellectual arena, some version of the rules/standards, science/art, foundationalist/antifoundationalist polarities formed a discourse around which positivism was being contested in various dimensions, all loosely referred back to the epistemological issue of truth as representation. The connection between positivism in social science, in epistemological assumptions, and in legal thought was vague at best. Some aspect of it is captured by an image of hardheadedness opposed to fancy but unrealistic theorizing, an image of a dichotomy between facts opposed to values, and the confidence in a sure marker for telling which was which. In a sense, various oppositions to positivist ideology were linked together, as discourses linking freedom and indeterminacy against constraint within the epistemological arena. This association seemed to assert itself even within what otherwise seemed like qualitatively different theoretical perspectives. Alvin Gouldner's depiction of the battle between scientific and critical Marxisms demonstrated the overlay of the issue of positivist methodology and left/right politics by showing the issue divided the left internally. ${ }^{192}$ Marcuse straightforwardly associated positivism with fascism. ${ }^{193}$ Within the Western left intellectual world, the critique of positivism served as one of the ways the left understood itself opposed to the centralized mockeries of popular control in the "Marxist" world. Thus the American New Left generally, like "European" or "humanist" marxists with whom they associated, rejected the scientistic, positivist aspirations of Marxism and made the critique of positivism the dividing line for disassociating from the large scale "socialist" regimes and ideology of the eastern bloc. ${ }^{194}$ The antipositivist characteristics of CLS work bear the marks of engagement with this recent intellectual history on the left.

\section{B. The Realists as Antipositivists}

At one level, the realists focused their attack on the liberty of contract ideology on the issue of representation. The common law judiciary's image of the liberty of contract as merely facilitative rested upon the assumption that the court could neutrally and determinately represent the act of will or consent with which the party obligated him-

192. A. GOUlDNER, THE Two MarXISMs (1980).

193. H. MARCUSE, REASON OR REVOLUTION (2d ed. 1955).

194. See M. Foucault, "Two Lectures," in POWER/KNowledge 84-92 (C. Gordon ed. 1980) (criticizing aspiration to make Marxism a science). 
self to the contract. Thus, not only did the liberty of contract approach depend on an image of a sharp dichotomy between the public and private realms - such that it was coherent to talk about a "private" decision free from public regulation - but it also depended on the idea that such a prior, private, and subjective moment could be faithfully re-presented at a later time by the court, as the basis for the legitimate imposition of legal duties. ${ }^{195}$ In this deep connection between the idea of a private will and the need to re-present that will publicly, from the outside, the common law formalists placed the objective theory of contracts. From this perspective, the objective theory plays the same role (with the same problematics) in private law that clear statement rules and other canons of interpretation play in traditional public law. They are attempts to objectify the practice of representation by the invocation of predetermined meanings that the relevant party is deemed to know. Simultaneously, this invocation serves to put the act of interpretation itself on a nondiscretionary basis.

Of course, there is an anomaly here: how can public, predetermined rules of construction hope to capture and reproduce what is posited as a unique event? That anomaly, reflecting the twin objectives of the ideology of liberal individualism both to represent private will, subjectivity, and yet to do so through law, on an objective and nondiscretionary basis, gives rise to the continuing dialectic about representation that is one preoccupation of twentieth-century American legal thought.

The commitment to protecting a sphere of subjective choice (whether that sphere is located in the individual or in the legislature) can be carried out in two paradigmatic forms, each of which is unsatisfactory. On the one hand, rules might be developed to govern the representational process, but as objective, pregiven rules, they are necessarily external to what is to be represented. On the other hand, a purposive or functional approach to interpretation may promise more sensitivity to the particularities of context and event, but at the expense of objectivity and determinacy, and thus may be vulnerable to the charge that it is not law at all. ${ }^{196}$

The realist attack on the liberty of contract approach can exploited this dimension of the problem of representation. The argument reap-

195. See Kennedy, Form and Substance in Private Law Adjudication, supra note 5, at 172831, 1754-56; Peller, The Classical Theory of Law, 73 CORNell L. Rev. 300 (1988); Peller, supra note 5 , at 1193-219.

196. For the exemplary study of the ideology of these modes of interpretation, see Kennedy, supra note 195. 
pears repeatedly in realist writings on contract law that the individualist pretensions of liberty of contract approaches were belied by the utilization of the objective theory of contracts. ${ }^{197}$ Rather than representing a prior act of consent, the objective theory of contracts necessarily constructed that will for social purposes. ${ }^{198}$ As Holmes said, the finding of contractual obligation rested on the congruence of external, formal signs, not on any internal will of the parties. ${ }^{199}$ Of course, that was only one aspect of the realist critique - but the rest of the realist attack revolved around a similar skepticism about the possibility of representation, a continual argument that the interpreter was constructing what she purported merely to represent.

This critique of representation had fairly direct and familiar implications for the substantive liberal political theory that underlay the liberty of contract approach. The inevitable indeterminacy involved in representing individual will reappeared in the more general critique of the neutrality and objectivity of common law doctrine that formed the "private" law of contract, tort, and property. A sharp distinction between the public and private realms was impossible because, in the very act of carving out the "private" domain, "public" policy necessarily interceded. Without any possibility of directly representing the market or individual will, both were necessarily socially constructed. Or, in other words, the doctrinal apparatus of the liberty of contract era constituted a particular form of social regulation, not the protection of the private realm from public intervention that the Lochner Court asserted.

Of course, on at least one interpretation, it seems strained to call the realists antipositivists. A significant strand of realist work clearly was positivist - the idea of law as prediction of official action contained in Holmes' "bad man" view of law,200 the separation of fact from values, 201 and the implication in much realist work that, although law inevitably involved questions of public policy, policy

197. A description of this aspect of realist scholarship is contained in Peller, supra note 5, at 1195-218.

198. Given the simplicity of this critique, one might well wonder how the liberty of contract theorists could have embraced the objective theory of contracts at all. It seems to us that the best explanation is that the objective theory of contracts was expected to mediate between private will and public interpretation through an image of objective standards of interpretation as elements of freely chosen and privately developing custom, reflecting the aggregate of individual decisions at any moment. Similarly, a negligence standard of reasonableness could cohere with an overriding individualistic legal theory on the same basis. See M. Horwitz, The Place of Justice Holmes in American Legal Thought (unpublished manuscript on file with authors).

199. Holmes, The Path of the Law, 10 HARv. L. Rev. 457, 464 (1897).

200. Id. at 458.

201. See Singer, Legal Realism Now, 76 CALIF. L. Rev. 465 (1988). 
analysis was itself objective and determinate - and hence lawyers could be understood as "policy scientists."202 In terms of this strand of realist scholarship, the idea that immanent social purposes could be identified and carried forth from the social field itself, or that prediction could represent objective factors upon which official behavior rested, constituted new claims of positive, objective representations. On this read, the realists turned the liberty of contract approach on its head: what was critical to represent was not the private subject, but the public, objective context - that is, more "facts."

\section{Procedural Representation}

The legal process thinkers of the 1950 s articulated the distinction between law and politics through the mediation of substantive pluralism on the one hand, and procedural determinacy, itself heavily dependent on the objectivity of representation, on the other. In their view, heeding the deep antipositivism of the realist critique would make the idea of being ruled by law incoherent. Yet the technocratic implications of the realist constructive program seemed inconsistent with the need for democracy at all. The response was typically relativist and inclusionary. Law was both the qualitative principles of common law formalism and the quantitative policies of regulatory science. Some realms were best left to expert resolution, others to reasoned elaboration - the pragmatic weaving together of principles and policies that defined the special judicial competence - and still others to resolution by the open-ended discretion of democratic choice. And the ultimate decision of which was which would be traced back to the popular will, insofar as other institutions acted as deputy legislators, to represent the absent legislature. In other words, the modernist pragmatism and indeterminacy were both embraced and constrained to issues of substantive law; "reasoned elaboration" was not meant to suggest any positive, predictable result in particular cases, because substantive doctrine had to be understood purposively, that is, in antipositivist fashion.

In Warshow, then, the movement from the majority's insistence that the nuclear protesters had not shown imminence to the procedural discourse of the dissent and concurrence was the background idea that, whatever else might make sense, imminence as a substantive, formal limit to the necessity defense did not. Thus, implicit in the

202. Harold Lasswell and Myres McDougal went the furthest in the attempt to develop this idea, see Lasswell \& McDougal, Legal Education and Public Policy: Professional Training in the Public Interest, 52 YALE L.J. 203 (1943), although much of the New Deal ideology of expert regulation might be traced to it as well. 
dissent and concurrence was the idea that a certain harm of small proportions was at least comparable to a small (but rationally unacceptable) risk of immense harm symbolized by the language of meltdown, unless you were prepared to take formalism quite far indeed. And once you abandon formalism for a purposive approach, you really do start wondering exactly what the protestors were trying to communicate before you excluded it as "irrelevant." But the legitimating ground for such an open-ended doctrinal approach was a procedural vision that made representation central to legitimacy.

The key assumption of the process approach, echoing the relativist defense of democracy in political theory, was that the indeterminacy of substantive questions was not all that subversive because substantive questions always were subject to legislative resolution. And the critical aspect of legislative resolution was the implication that the legislature "represented" the popular will. On this fulcrum, the image of common law courts and administrative agencies as "deputy legislatures," legislating "interstitially" and subject to legislative correction, links together with the reigning constitutional law idea of the "countermajoritarian difficulty." Both acquired their particular meaning in reference to a legislature that ruled by virtue of its democratic character, that is, to the extent that it represented the popular will.

More generally, under the principle of institutional settlement, the "special kind of ought" of law always depended on the ability to represent the conjunction of a particular kind of question with the particular procedure that ought to be employed to resolve that kind of question. For example, if what made administrative agency decisions legitimate was the legislature's delegation of authority to administrative application of "expertise," then an agency decision must demonstrate that expertise to the court if it is entitled to respect under the principle of institutional settlement. And because the possibility of objective representation was limited to institutional competence analysis, the bulk of process-oriented scholarship consisted of studies of institutional interrelationships. The critical issue in such studies was always whether or not to defer to another institution's resolution of a substantive issue because that institution's resolution "represented" the congruence of a particular procedure and the kind of issue that procedure was rationally adapted to resolving. ${ }^{203}$

Warshow was in this sense an exemplar case for process theory. In

203. See, e.g., F. Frankfurter, The Public and Its Government (1930); H. Hart \& H. WeChSLER, supra note 2; H. Wellington, LABOR AND THE LEgAl Process (1968); Bator, Finality in Criminal Law and Federal Habeas Corpus for State Prisoners, 76 HARv. L. REv. 1 (1963). 
Warshow, concurring Justice Hill's argument that the balancing of the risks and benefits of nuclear power had been accomplished in the democratically chosen manner by the Nuclear Regulatory Commission reflected one highly formalist version of the possibilities for identifying institutional legitimacy. He did not even seem to care whether or not the Nuclear Regulatory Commission procedures had arguably failed in this particular licensing; he was willing to review the decision at the highly abstract level of whether or not nuclear power had been decided to be worth its risks in general.

The process synthesis was also its vulnerability, for its pluralist inclusion of form and function would soon bleed over from substance to process. Indeed, throughout the hegemony of process theory in the late 1950 s and 1960 s, one could fairly easily distinguish liberal from conservative process theorists based on whether they used a formal or purposive approach to the question of how to represent institutional legitimacy. In the example of an administrative agency, one could identify expertise in a rule-like, formal matter - did the decisionmakers have appropriate degrees, did they spend time studying the issue - or in a functional way that moved closer and closer to having to reproduce the very substantive decision in order to determine whether or not expertise was exercised. In labor law, the issue was "does an employer bargain in good faith" - the procedure legitimating labor/management relations - when it simply meets with and exchanges words with union representatives, or must we look to the substantive question whether reasonable labor proposals were rejected without justification? But such a choice between formalist or functionalist ways to identify legitimating procedures implied that the question of whether any particular institutional decision was entitled to respect itself was indeterminate, undercutting the logic of turning to proceduralism in the first place.

In Warshow, the dissent showed the ultimate overlap between the substantive and procedural questions. Suppose the protestors were right, and starting up Vermont Yankee presented unreasonable risks of nuclear catastrophe, either slowly over time or all at once at some unspecified time. In that case, they necessarily claimed implicitly that the regulatory apparatus the "public" set up to ensure its safety had messed up tremendously. A necessity defense neatly countered both a substantive and proceduralist formalism once a purpose was given to public agency creation - what kind of public would set up an agency to approve unreasonably dangerous nuclear power plants? Every claim of unreasonable nuclear risks was automatically a claim of agency failure. The very logic of having a necessity defense - to sub- 
categorize the dictates of the general criminal law to exceptional contexts where the values protected by the general law are outweighed in particular circumstances - suggested conducting the institutional calculus in a nonformalist, contextualized way.

While the indeterminacy of such concepts as "expertise" and "good faith bargaining" - to say nothing about "due process" - provided the organizing agenda for controversy among legal scholars within the process discourse, the key predicate to the whole approach - that the legislature represented the popular will - was itself simply assumed. The deep anomaly of the relativist theory of democracy, as well as the legal process reconstruction of law around it, was that relativism could just as easily invade the question whether or not a democracy prevailed in the first place. The range of ways to "represent" legislative legitimacy could extend from formal, external signs, like the positive fact of voting and the obedience to the formal requirements of presentment and bicameralism, to a critical and substantive inquiry into the quality and experience of social freedom actually enjoyed in the society. The legal realist deconstruction of the idea that the common law represented individual consent could apply to the idea that the legislature represented popular will. Early process theorists avoided the anomaly by ignoring the issue altogether.

John Hart Ely is a transitional figure in the development of the New Public Law because he opened the process discourse to the critical questioning of the democratic legitimacy of the legislature. This inquiry forms the starting point for understanding the more complicated position that New Public Law adopts. Prior to Ely's work, scholars in constitutional law had simply assumed the predicate of the "countermajoritarian difficulty," that the legislature represented the popular will, and occupied themselves with the theoretic consequences of that starting point for judicial review. Ely in a sense perfected process theory. ${ }^{204} \mathrm{He}$ completed the general institutional competence system by resting judicial review on the necessity to ensure that the legislature is truly representative, in much the same way that Hart and Sacks talked about judicial review of administrative decisions as necessary to ensure that administrative decisions are supported by expertise. Ely's work, by neatly integrating Brown into the process analytic, vindicated "liberal" process theorists for whom Wechsler's "Neutral Principles" argument had hung like a cloud over their work.

But no sooner had Ely focused on the legitimacy of the legislature

204. See Parker, The Past of Constitutional Law - And Its Future, 42 OHIo ST. L. REv. 223, 223 (1981). 
than the conflict between a formalist or purposive mode of review immediately represented itself. This conflict arose in the interstices of doctrinal questions such as the choice between a de jure or de facto approach to whether or not "discrete and insular minorities" had been burdened, or whether or not the state action doctrine made sense as a precondition of first amendment rights. Ely's key insight was that the same idea of legislative representation which formed the starting point of the "countermajoritarian difficulty" itself provided the task of activist judicial review - to ensure that the legislature really did represent popular will (here understood in interest group pluralism terms). But once Ely centered the issue of representation, the choices between purposive and formalist approaches immediately reappeared. The representation-reinforcing mode of judicial review could be conducted either on a formalist basis or through a more open-ended, and indeterminate, interpretation of whether or not American society was democratic. Given that the legislature did represent the popular will, a constrained, rule-like review would be in order to ensure that the judiciary did not invade the competence of the legislature. Still, this conclusion could not be taken as a given, and thus utilized as a way to resolve whether or not to approach legislative legitimacy in rule or standard fashion, because it was the very question at issue. In scholarship, the indeterminacy of representation of the category "democracy" was reflected in critical reviews of Ely that argued for alternative definitions of democracy. ${ }^{205}$ Moreover, some argued that deference to the legislature was problematic even when discrete and insular minorities were not at issue, because the legislature could not be assumed to represent the majority. ${ }^{206}$

In antidiscrimination law, the question reappeared in the trenches of doctrinal debate over intent and impact tests; in first amendment law, over the state action doctrine. In each of the settings, Ely's own resolution of the issue of representation appeared more and more formalist: limiting the inquiry to whether or not the state had acted to violate a checklist of democratic criteria provided in the Constitution (voting and free speech) seemed to beg the functional question whether or not, even apart from state action, discrete and insular minorities or free speech rights were burdened. If the opportunity to exercise free speech rights was an empirical precondition to legislative legitimacy, the legislature could not be said to be democratic unless those opportunities actually existed. And after the realist assault on

205. See Constitutional Adjudication and Democratic Theory, 56 N.Y.U. L. REV. 259 (1981); Symposium: Judicial Review versus Democracy, 42 OHIo ST. L.J. 1 (1981).

206. Parker, supra note 204, at 246-59. 
the public/private distinction, limiting the inquiry to the positive acts of the state seemed especially backward. The legislature's failure to act affirmatively arguably created legally enforced privileges on the part of shopping center owners to deny free speech opportunities. And yet, without the kind of limitations assumed by Ely, the representation-reinforcement would devolve into the kind of free-wheeling inquiry into social justice that the entire process approach assumed to be hopelessly indeterminate and value-laden. Process theory was at an intellectual dead-end.

In any event, just as Ely seemed to perfect the process synthesis, the process approach itself had become a background and waning conventionality. The politics of representation took the more explicit form of an opposition between objectivist and positivist law and economics and the antipositivist critique in CLS. By the time that Ely successfully integrated legal process with the activism of the Warren Court, the heart of the legal process approach had passed from liberals like Lon Fuller and Henry Hart to conservatives like Paul Bator and Paul Mishkin. Instead of reflecting the constitutional activism of the Warren Court, the authoritative decisions reflected the deregulatory activism of the Burger Court. And the central process admonishment to defer to decisions under the principle of institutional settlement had assumed a broader, conservative cast as the underpinning of "establishment" objections to the confrontational protest and mass mobilization tactics of progressives in the 1960s. For liberals who wanted to support Brown and the most progressive Warren Court decisions, Ely's own synthesis did little to relieve their sense of intellectual disintegration and ideological isolation.

\section{Polarization}

As the "center" represented by process discourse waned, the pluralist theoretical synthesis disintegrated back into its positivist and antipositivist components. The ideological disagreements between the law and economics and CLS movements had many different dimensions, including vast conflict over the legitimacy, definition, and coherence of the private market and the role of law in the construction of social power. One overriding point of opposition was the dramatically divergent positions each movement symbolized with respect to the issue of representation: it seemed like a localized battle neatly divided between "science" and "critical theory."

The contrast was apparent early in the ways that each attacked the centrist conventionality of legal process in the 1970s. According to law and economics scholars, the problem was a lack of real world ana- 
lytic rigor. Hart and Sacks built implicit ideals of New Deal social reformism into the judicial task of "reasoned elaboration." Ad hoc judicial regulation of economic relations between manufacturers and consumers or carriers and shippers exemplified this task. Such attempts were all misguided at best and mush at worst. From a more systematic view, such piecemeal social reform was counterproductive. The market would swallow up all attempts at legal reform. Indeed, using the market as an objective ground, determinate predictions could be made as to the social effects of particular legal rules, and the history of the law itself could be understood as the working out of a determinate drive toward market efficiency. ${ }^{207}$

Where the right purported to attack from an objectivist base, the left attacked from an antipositivist ground. What the center had taken as simply pragmatic and technical questions of whether to regulate by rules or standards, or through negligence or strict liability, were not simply technical questions at all, but implicated fundamental ideologies about social life. ${ }^{208}$ Moreover, the liberal image of achieving justice through the distribution of legal rights was incoherent because it rested on the same public/private formalism that the realists had already demonstrated was indeterminate. Rights discourse was analytically zero sum; appeals always existed to contradictory claims to rights to freedom of action and rights to security from harm. ${ }^{209}$ Which appeal to recognize in a particular context depended on more than the commitment to legal rights themselves. Law might be understood, not as the rational accommodation of conflicting social interests, but as the site for the production of a ruling ideology about the necessity for the existing arrangements in social life. ${ }^{210}$

More than the contrasting attack on the process; ideology defined the polarity between law and economics and critical legal studies. There was also important ideological baggage associated with the contrast between methodology - the determinate, hard-edged, quasi-scientific rigor of economics and the indeterminate, socially-constructed, anti-objectivist tenor of CLS scholarship. Thus, rather than attacking the market ideology of the Right as based on the "wrong" values, or from a traditionally liberal ground as the impermissible imposition of value itself, critical legal studies focused on the claims of representation, on the pretensions of law and economists to be able to describe

207. See, e.g., R. Posner, Economic ANALysis of LAw 359 (3d. ed. 1986).

208. See Kennedy, supra note 195.

209. See Singer, The Legal Rights Debate in Analytical Jurisprudence from Bentham to Hohfeld, 1982 WIS. L. REV. 956 (1982).

210. See Gordon, supra note 5. 
and predict a world separate from the metaphors used to comprehend and interpret that world. Against the idea that preferences simply exist separate from the act of interpretation and then are represented in Pareto-superior transactions, Mark Kelman argued that preferences could not be assumed to be exogenous to social structure.211 Similarly, CLS writers argued that the evaluation of levels of satisfaction under an efficiency analysis was always potentially indeterminate. Duncan Kennedy combined the indeterminacy of the choice between offer and asking prices with the elasticity of the concept of transaction costs to suggest that the efficiency calculus was inherently indeterminate. Third-party preferences of everyone could always be considered at either their offer or asking prices with widely different results in particular cases. Furthermore, the description of the status quo from which to identify a change in regimes was itself an indeterminate exercise. As a result, the potential Pareto-superior welfare calculus, the KaldorHicks test, was indeterminate. ${ }^{212}$ And finally, Kennedy and Frank Michelman systematized the critique to demonstrate that no efficiency conclusions could even be drawn about the basic ideas of private property or free transferability. ${ }^{213}$

We justify this absurdly brief and simplified description of the rise of law and economics and CLS in the 1970s, because our goal is not to consider the details of the arguments over the competing approaches, but instead simply to set the context for the appearance of the New Public Law in the 1980s, in terms of the context over a polarized scholarly discourse divided on one dimension, and over the politics of representation that the realities introduced in American legal thought.

\section{E. The Social Construction Point}

We have been leading up to the argument that what connects various aspects of the New Public Law scholarship together is an antipositivist stance toward interpretation. We here want to draw these connections more explicitly by developing some important possible consequences to be drawn from the idea that law is socially constructed.

From a political theory point of view, perhaps the most important implication of New Public Law's embrace of the antipositivist position is its rejection of the public/private distinction as a coherent way of

211. M. KELMAN, supra note 182 at 114-86.

212. Kennedy, Cost-Benefit Analysis of Entitlement Problems: A Critique, 33 STAN. L. REv. 387 (1981).

213. Kennedy \& Michelman, Are Property and Contract Efficient?, HoFsTRA L. REv. 711 (1980). 
thinking about political legitimacy and social order. Critical legal scholars, radical feminists, and left scholars of color subscribe to a common analytic. They seek to debunk the foundational image of liberal theory that the world can be divided into strict public and private spheres, and that the task of political and legal theory is to figure out how to protect the private realm from overreaching public power. Thus, the left critique of the market has emphasized that there is no analytically coherent distinction between the free market and social regulation. When the state purports simply to stay out of the market by refusing compensation for specific acts, it in fact creates legal privileges to injure without the duty of paying compensation. ${ }^{214}$ In radical feminist literature, the idea that, without intervening, the state leaves family relations private has been debunked by the demonstration that such a posture creates a legal privilege on the part of wife-abusers to abuse without legal recourse. ${ }^{215}$ And similarly, the idea that colorblind neutrality entails racial equality has been questioned by an emerging radical voice of color that sees white assumptions posing as neutral universals. ${ }^{216}$

New Public Law scholars have utilized this kind of updated realist critique of liberalism to reject the image of the private sphere as somehow natural or objective. Thus, borrowing from more radical analyses, Cass Sunstein utilizes the Hohfeldian analytic to contend that the common law itself is a form of economic regulation and therefore cannot be taken as a neutral baseline for evaluation. ${ }^{217}$ Accepting that there is no qualitative distinction between the market and regulation, Sunstein then proceeds to list the various factors he thinks are relevant to determining which mode of regulation to pursue; in his image, it is often largely a functional, technocratic task of fitting a regulation strategy to a particular empirical context.

One implication of rejecting the positivist identification of a private realm is a general rejection of liberal ideas of economics and the market. For example, an assumption of most neoclassical, liberal economics thinking is that tastes and preferences are exogenous to the market. Thus, rules adapt to exogenous preferences, not the other way around. This assumption flows from the particular premise that individuals exist as self-contained unique beings and are the analytic starting points

214. See Singer, supra note 201.

215. See Olsen, The Myth of State Intervention in the Family, 18 MiCH. J.L. REF. 835 (1985); MacKinnon, Pornography, Civil Rights, and Speech, 20 HARv. C.R.-C.L. L. REv. 1 (1985).

216. Crenshaw, supra note 185; Williams, The Obliging Shell: An Informal Essay on Formal Equal Opportunity, 87 Mich. L. REV. 2128 (1989).

217. Sunstein, Lochner's Legacy, 87 CoLUM. L. REv. 873, 880-82 (1987). 
of economic theory. But just as the antipositivist tendencies of the New Public Law scholarship deny the sharp distinction between the private market and social regulation, they also incorporate what has long been the position of left, and particularly socialist, ontology, that the individual subject, including her tastes and preferences, exists in a dialectical relation to social context and social structure. To put this another way, no subject is separate from objective and external social conditions. Thus, instead of accepting the assumption of liberal theory that the individual is the analytic starting point of social theory, New Public Law scholars conceive that individuals are formed and transformed in their social relations, and that it is social relations that give content and meaning to individuals. The theoretical correlate to this position is the assertion that tastes and preferences are endogenous to social structure. In short, part of the left drift of New Public Law scholarship is rooted in these essentially communitarian ideas about identity formation.

The commitment to a dialectical vision of the individual and the social structure and of the relation of economic markets to legal regimes evidences a theoretical opposition to more general liberal oppositions between subjectivity and objectivity, self and other, market and regulation, private and public. This analytic is evident in other scholarly manifestations as well. Take, for example, the new hermeneutics in constitutional and statutory interpretation that we have described. Against the traditional image of a self-contained and positive text (a statute or constitution) capable of neutral, "accurate" interpretation by a disinterested reader, the New Public Law poses the image of a text as essentially open-ended and incomplete, having no determinate and positive meaning separate from its interpretation by judges and citizens. "Dynamic" statutory interpretation, the rejection of the old canons of interpretation, and the image of constitutional lawmaking as existing beyond the formal enactments of legislatures and courts are all pieces of the general rejection of a positive meaning capable of simply being represented by an observer who is otherwise separate from the text. Instead, representation is inevitably interpretation; a text has no meaning separate from this process. The observer and the observed are dialectically linked.

This adoption of a "postmodern" stance toward identity and interpretation has been linked to a new "anti-formalism"218 in constitutional scholarship. One can trace an increasingly anti-positivist 
development from Ely ${ }^{219}$ to Ackerman ${ }^{220}$ to Michelman ${ }^{221}$ in constitutional scholarship. Compared to the simple assumption of the democratic character of American society to the earlier generation of process-oriented constitutional theorists, Ely's work seemed a critical breakthrough, demonstrating the legally created nature of the democratic decisionmaking process. But, to the extent that Ely ties his reading of the Constitution to the language of the document, Ackerman's suggestion that focusing on the text improperly excludes what we should see as of constitutional moments such as the mobilization of political energy represented by the New Deal as the basis for interpretation seems antiformalist. ${ }^{222}$ Certainly the New Deal represented a conceptual and social reordering. Moreover, Ackerman exposes the contingency of Ely's association of "democracy" with the extant legislature through the identification of supra-majoritarian shifts in norms that were obviously also rooted in democratic, popular will. Compared to Ely's text-based structure, Ackerman proposed deformalizing judicial review by resting it on something like the New Deal "moment" of popular, informal constitutional amendment. ${ }^{223}$

Michelman could then continue the antipositivist practice by criticizing Ackerman's limitation of popular constitutional lawmaking to extraordinary historical moments. According to Michelman, Ackerman's invocation of such clearly bounded and identifiable "constituting moments" was itself a formalist, or "authoritarian" demand to abdicate responsibility by deferring to something outside and external to context. Such constitutional moments might be created at various times and their creation may itself depend on official recognition by the courts, Michelman suggests. Hence the idea of normativism is central to one version of New Public Law discourse. Responsibility could not be abstracted away by purporting to represent something external to the decisionmaker like a distant, dramatic, historical moment. In Michelman's extraordinary argument, the countermajoritarian difficulty was precisely flipped. The need to defer to a democratic decision meant that the judiciary must identify selfgovernance on a nonformalist basis. One would not, for example in Warshow, simply defer to the Nuclear Regulatory Commission's decision simply because of its formal status. Instead, democratic moments

219. See J. ElY, supra note 90.

220. See supra note 99.

221. See supra note 53.

222. See Ackerman, supra note 98, at 1051-57.

223. Id. 
of social life can be identified outside official space, in social movements or cultural change, and law has a role in its creation.

Just as the representation of democracy was transformed from the legislature to the dialogic courts, the old legal process formalism about courts was being challenged in progressive public law scholarship. Specifically, this literature challenged Fuller's identification of the judicial role with nonpolycentric disputes. ${ }^{224}$ The ideas of public values in statutory interpretation similarly deformalized the conventional perception of the relationship between text and interpreter.

In short, in our view, what ties New Public Law scholarship to CLS, and gives it the general flavor of a left and progressive tilt, is the embrace by New Public Law scholars of the critique of positivism that radical scholars have developed to criticize liberal theories of the market, the self, knowledge, and interpretation. This critique has led to a general conception of the socially constructed character of the market, preferences, and assertions of truth that have recently been associated with "postmodernism."

\section{F. Different Things the Social Construction of Law Could Mean}

In this section, we briefiy compare the different routes through which leftist and centrist scholars are arriving at the common ground of a critique of "positivism" or "foundationalism" or "jurispathic" interpretative stances. We then describe what we think are the different implications that the "social construction of reality" might have.

If we are right in our description so far, we can generally conclude that, in terms of intellectual premises, very little separates New Public Law and CLS scholars. And yet, work from the two approaches evidences an unmistakable difference in tone and style. We believe that these differences are ultimately political and cultural. They have to do with the degree to which different people associate with an oppositionist rather than a reformist stance toward dominant institutional life that is difficult to "account" for. But there is also, we think, an analytic or intellectual correlate to the differences between the CLS and New Public Law postures that is more accessible. Let us start there.

Although both New Public Law and CLS scholars make central the idea of the social construction of reality, of law, of individuals, of the market, and of what they call "democracy," this idea has different meanings for the two sets of scholars. These divergences can best be explicated from an analysis of the intellectual lineage through which both groups arrive at this idea.

224. See Fiss, supra note 99. 
This issue is easiest to grasp by looking historically back to the realist critique of the liberty of contract ideology. When the realists debunked the liberty of contract era as "formalist," as "transcendental nonsense," the implication was that the old order thinkers had simply made an intellectual error. They mistook doctrines like "duress" and "mutual assent" in contracts, for example, as if they were real things existing in the world that the legal categories simply re-presented. Except to suggest that the liberty of contract judges were ruling based on their personal preferences, the realists never tried to connect the "formalism" of the old order with a social theory that could explain why liberty of contract theorists might have made the "mistakes" they made. Nor did they articulate the significance, in terms of the constitution of social power, such an approach might have made. This probably has been the greatest difference between the legal realists and the CLS work. While the realists were content to delegitimate the purported neutrality and objectivity of the old order (in order to clear the ideological space for governmental regulation, the New Deal, and governance through administrative agencies and policy-oriented courts), CLS scholars have utilized the realist deconstructive analytic to begin a discussion about the ideology and politics of law. Although emphasizing different factors in the role that law plays to constitute the terms of social power and the boundaries of what gets perceived as just or unjust, CLS writers by and large have connected the internal intellectual critique of liberal legal and political thought to the outer experience of social life and the application of social power. Rather than see the claims of law to objectivity, neutrality, and determinacy as simply intellectual mistakes, they have found in mainstream legal doctrine the elements of an ideological discourse for representing and interpreting the social world. This discourse works as one mode of social power.

To put this another way, CLS scholars have approached law from the viewpoint of social theory, and have asked how the law generally works to appear neutral and noncontroversial despite the intellectual emptiness of such claims. And by pursuing a vision of legal discourse either as legitimating a particular form of social relations ${ }^{225}$ or as embodying the political struggle over how to describe and understand social life, CLS work is absorbed with the political character of law, and the manner in which claims to neutrality, objectivity, and determinacy - the aspects of legal discourse that we have called positivist work to deny and repress this political, socially constitutive quality of law. The debunking of pretensions to some rational or scientific way

225. See, e.g., M. HoRwitz, The Transformation of AMERICAN LaW 1780-1860 (1976); C. MACKINNON, supra note 114. 
to generate legal results, the critique of positivism in law, has been part of a project to politicize law, to expose the social conflict and power dimensions obscured by universalist interpretations of social life.

This conflict-oriented, politicizing character of CLS work distinguishes it most profoundly from New Public Law scholarship. New Public Law scholarship is oriented to consensus rather than conflict, to rationalizing rather than politicizing legal issues. This commitment to consensus and rationalization characterizes the emphasis of New Public Law scholarship on pragmatic deliberation and diversity. Once one abandons the centralizing and universalizing claims to foundationalist law, once one gets beyond the formalist limitations that liberal legal thought imposed, once the proper safeguards against factionalization are in place, and once all relevant viewpoints are empathetically "attended to," then the polity, or the judge as surrogate for community deliberation, can reach a result that gives credence to the widely different places that we occupy in the social structure.

This ultimate consensus-orientation of New Public Law scholarship underlies the tension we articulated at the beginning of this Part. The rejection of traditional notions of objectivity and neutrality leads these scholars to emphasize "normativity." Commitment to a normative program has, at least since the realists, implied commitment to politicization. But an aversion to conflict drives the other side of the tension, the idea that justice exists in procedures and conversations and deliberations which ultimately will yield just results. Like many realists, New Public Law scholars tend to see the issues of positivism and formalism as mistakes that past elites have made in managing the reins of formal social power rather than themselves factors in the economy of social power, the link between neutrality and power presented as law. And their solution, stated most generally, is to correct those mistakes by substituting a new, deformalized, and freewheeling decisionmaking process. Thus, even Frank Michelman, arguably the New Public Law scholar most committed to an antipositivist position, comprehends his work as "republican-inspired" and "process-based."226 If we are right about all this, then we can expect the critical intellectual issues within the New Public Law to revolve around the issue of cultural conflict, of how to choose one description of the actual experience of social reality over another.

For many, part of the appeal of the New Public Law approach is the implicit suggestion that accommodation to the diversity of social voices can itself avoid cultural conflict. Thus, in our discussion of the

226. Michelman, supra note 171 , at 1537. 
Gay Rights Coalition case, we utilized as a New Public Law exemplar the way that Judge Mack sought responsibly to address the conflicting issues of community identity presented by gay students and Georgetown as a Catholic university.

The New Public Law suggests a resolution of this kind of social conflict in one sense by according a normative status to processes of decisionmaking (informed deliberation, openness to diversity of views, and accommodation). Like Frank Michelman's invocation of Justice O'Connor's opinion in the Goldman case, ${ }^{227}$ our analysis of Judge Mack's opinion focused on these characteristics. But once the antiobjectivist project gets going, it is difficult to contain. How would one recognize a legitimate decision in the Gay Rights Coalition case from the criterion of "attending to the dignity of each community"? Even beyond the acknowledgement that the case involves "conflicting norms," it seems clear that if we continue to the process of the postmodern interpretivism that the New Public Law proclaims, it seems especially limited to see the case as a simple collision of the selfgoverning dignity of two communities - gay students and the Catholic integrity of Georgetown University. Even identifying the conflict as such is an ideologically and culturally driven social construct, since it is simple to imagine other ways to describe the context. Just as it was possible to imagine a realist-inspired critique of objectivist applications of the necessity defense in Warshow, it is possible here to problematize any particular identification of the communities vying for self-governance in the Gay Rights Coalition case. For example, one cannot take the integrity of the Catholic doctrine on homosexuality as a "given" value important for Catholic self-governance, since the issue is a point of struggle within the Catholic community itself, and the court's treatment of the case in fact will become at least one small factor in that struggle. ${ }^{228}$ Similarly, the legitimacy of the university to operate a decentralized, autonomous cultural institution within the community of Washington, D.C., is also not self-evident. To the extent the university plays important roles in both the material and symbolic economies of power within Washington - roles it has cultivated as part of its drive for national elite recognition - it is arguable that it cannot be seen simply as a "Catholic university."

Situating the cultural conflict in the Washington urban scene also brings into relief the connection of the issue of the legitimacy of Georgetown's autonomy from municipal human rights regulation with

227. Michelman, supra note 53.

228. See supra note 144. 
American racial politics, given that part of the University's identity is as one of the "national" and largely white institutions located within a largely African-American community. More deeply, the "accommodation" reached by the court's decision in the Gay Rights Coalition case may in fact insult both communities. For mainstream Catholic self-identity, the formal lack of university "recognition" may be just that, a formalism; the court's requirement that university facilities be made available is surely offensive to some Catholics. For gay students, the degrading symbolism of differential nonrecognition by the university may be more insidious than the functional question of access to facilities, in light of the lack of historic ties between homophobia and systematic economic degradation. Finally, it is not clear that participation in dialogue will transform the conflict over gay rights in the Catholic community into a transformative new accommodation. A difficult political, cultural choice to "kill" the aspirations of one or the other relevant communities may be inevitable in this interpretation of the context. And there may be no way even to describe the context that is not already situated in some structure of power.

In short, once the commitment to an antiobjectivist practice is made, it should be immediately clear that in a case like the Gay Students Coalition case the very act of describing the dignity and cultural conflict at issue reintroduces significant issues of politics, power, and ideology. Neither the "Catholic community," "gay and lesbian students," nor "Georgetown University" are autonomous, free-standing cultural givens. Their identities as communities are issues of constant struggle and conflict, and those struggles in turn will be influenced by how the judiciary responds. Just as the realists argued that rights could not be the ground for legal decisions since they were the consequence of legal decisions, neither can community identity in a republican ideal of "self-governance" provide the support for a simple diversity approach to the Gay Students Coalition conflict, since the legitimacy of each community is, in part, precisely what is at issue in the case.

Deformalizing the sources of law to include a hermeneutic story about a statute's meaning, or to encompass the daily acts of constitutional lawmaking that occur in the streets, schools, workplaces, and bedrooms of American social life, cannot in and of itself avoid political choice.

In contrast to the CLS movement, whose goal of politicizing law tends to be associated with a general political project of resistance to status quo forms of social power, the New Public Law is characterized by a common attempt to stop analytically short of the radical implica- 
tions of an antipositivist, postmodernist intellectual culture, and ultimately to depoliticize questions like those posed in Gay Students Coalition. On the one hand, what gives the New Public Law scholarship its left-tilted flavor is the adoption of postmodernism as an interpretative and epistemological position. Like the left, New Public Law scholars are identified with an intellectual opposition to objectivism, formalism, and positivism. In this dimension, the New Public Law scholarship completes the process begun in one sense by the legal realists. The realist project of demonstrating the political and socially constructed character of law was domesticated by early legal process theorists who contained the realist antiformalism to substantive questions. Beginning most vividly in constitutional scholarship with Ely, and culminating in the work of Michelman, New Public Law scholars for the last fifteen years have been steadily eroding the process synthesis by extending the realist debunking from substance to procedure. ${ }^{229}$

On the other hand, New Public Law scholarship is distinct from the left in its moderation of the implications of the postmodern situation. The rhetorical manifestation of this dynamic is the notion that CLS is "not positive" or "goes too far." The conceptual manifestation is the point at which New Public Law scholars characteristically transform political, cultural, and ideological conflict into a realm of discourse - republican dialogue and deliberation - in which the particular conflicts are re-imagined in the context of a broader, universal interest in community and understanding.

There are four strategies followed by New Public Law scholarship that are distinguished by their respective attempts to dedicate the social conflicts exposed by critique of institutional formalism. We will discuss these four strategies in the order of their relationship to the objectivist tradition.

The most objectivist-oriented response is the technocratic one; in this kind or work, the assumption is that conflict is more apparent than real once all the "facts" are collected, or once the "distortions" identified by public choice analytics are accounted for. The animating idea here is that there is a functionally normative resolution to social conflict available. ${ }^{230}$ But most New Public Law scholars believe that something more is at stake than "balancing and accommodating the relevant values" in a case like the Gay Students Coalition. Somewhat

229. See, e.g., Michelman, Norms and Normativity in the Economic Theory of Law, 62 MINN. L. REV. 1015 (1978).

230. See, for example, the emphasis on information collection, and on the functional correlation or typology of market failure and kind of regulatory response, in C. SUNSTEIN, AFTER THE RIGHTS REVOLUTION (1990). 
less objectivist and more politically progressive is a second sub-genre of New Public Law that attempts to find the normative grounding immanent in the social world itself; the idea here is to ensure "coherence" between law and nonformalistically identified social values. But if simple coherence is the test, then the New Public Law would devolve into a kind of proceduralism where the only critical requirement was to listen to interested parties about how disputes should be resolved. The pragmatic, antiformalist test of "hanging together," of coherence with social understandings, also cannot avoid political choice in a situation of conflict. On the interpretivist assumptions of New Public Law scholars, the identification of progressive social meanings cannot be governed by something "outside" the act of interpretation; that is the flight from responsibility that Michelman articulates. ${ }^{231}$ As Margaret Radin has argued, if the deformalized lawmaking is justified by its "coherence" with informal norms and understandings in society, nothing in the pragmatic stance distinguishes between "bad coherence," that is, coherence with existing structures of domination and illegitimate hierarchy, from "good coherence," that is, coherence with progressive and liberating strands of modern life. ${ }^{232}$

Radin's own solution is to meld pragmatism with a particular form of cultural feminism which contends truth can be found in the experience of dominated females - but such an approach tends toward a "third-worldism" that became fashionable in the 1960s. Within that school, the discourse of the oppressed was valorized as containing authenticity simply from the experience of oppression itself. Other New Public Law approaches in this sub-genre include the idea that simple empathy with the position of the "other," or a focus on concrete experience rather than abstract legalism, can somehow be the ground for an acceptable resolution of social conflict. The animating idea behind these approaches is that injustice flows from a kind of narrow-mindedness that can be cured by truly attending to the perspectives of others, with the implicit assumption that multiplying perspectives to achieve "perspectivalism"233 will bring one closer and closer to the truth of a situation. ${ }^{234}$

Michelman exemplifies yet a fourth sub-genre of New Public Law scholarship. Taking the antipositivist critique to its existential implications, Michelman rests the authority of social decisionmaking on the

231. Michelman, supra note 53.

232. Radin, supra note 153, at 1710.

233. See, eg., Minow, supra note 55, at 76-82.

234. For a critique of the optimism of this kind of intellectual pluralism, see Ehrenreich, Pluralist Myths/Powerless Men, 99 YALE L.J. 1177 (1990). 
good faith conviction of the decisionmaker who has overcome bad faith reliance on some authority divorced from her own influence (the jurispathic) and instead taken moral responsibility for her relationship to the social conflict of a case like Gay Rights Coalition. In the family of New Public Law strategies, Michelman's position on the left of the group is related to the degree of his embrace of postmodern epistemology: In his vision, there is no objective and free-standing basis for the exercise of social power, only the thoroughly decent norm of respecting the communities outside of one's own. Part of the New Public Law's motivation and discourse is a desire to avoid a politicized legal discourse that has been the aim of CLS scholarship. Instead, New Public Law scholars favor images of dialogue, diversity, and pragmatic reasoning to achieve just social results. These scholars have borrowed the analytics of the realists and CLS in order to deformalize the centrist legal ideology that process theorists in the 1950s developed. Given the change in historical situation, demonstrating the objectivity of the procedural inquiry is simply not as important as it was in the post-war period, and thus formalism has lost its usefulness. And thus we have the beginnings of a process-oriented discourse that has as its centerpiece an informal, open-ended, and antipositivist view of process itself.

\section{G. Centrism as a Postmodern Cultural Form}

The intellectual context we have described, of polarized discourse and ideological estrangement with the collapse of a center, was (is) not peculiar to law. The story of a 1950s pluralist consensus around proceduralism and pragmatics with an undercurrent assumption of fundamental consensus that would weaken in the 1960s, and explode into polarized movements in the 1970 s and 1980 s, actually describes a strand of the contemporary history of dominant American intellectual life generally. Although the particular spin is different in each field, this basic structure captures the fractures across the intellectual space. In literary criticism, for example, the pluralist movement in the 1950s was represented by New Criticism, a loose, pragmatic and pluralistoriented critical practice whose main object was to interpret the text in terms of its inner meaning and interconnections. In the late 1960s and 1970s, this kind of criticism, which seemed so exciting in the 1940s and early 1950s, would seem to run out of steam and inspiration the further it was from its founding conflict with older, essentialist-oriented critical techniques. Structuralism represented the first radical threat to the New Criticism that would finally culminate in the more radical deconstruction claims of Derrida, De Man, and their follow- 
ers. ${ }^{235}$ Just as law and economics reflects in law a right-wing reaction to both the mushy center and the radical left, so too has the rise of deconstructive critical approaches in literary criticism spawned a conservative traditionalist reaction. This conservative movement is characterized by calls for a return to the integrity of the text, imagined as either the intent of the author, or a new attention to literalism and objectivism in interpretation. ${ }^{236}$

In history, the 1950s methodology was explicitly consensus-oriented, ${ }^{237}$ to be challenged by the late 1960 s and early 1970 s by both neo-Marxists, who uncovered the social struggles suppressed by the benign consensus stories of teleological progress, and by wilder, speculative genealogies and histories produced in Europe by Michel Foucault and others. ${ }^{238}$ The radical challenges to the boundaries of historiography produced its own reaction in new conservative historians looking toward a classical development and telos, as represented by followers of Leo Strauss and others. ${ }^{239}$ And philosophy, anthropology and psychological theory have followed a similar path. ${ }^{240}$

The politicization of legal discourse in the 1970s and early 1980s, and the increasing sense of ideological polarization with no center around which to orient positions, is not unique to law. Instead it reflects a broader dynamic in late twentieth-century Western intellectual life. It is part of a large-scale injection of what has been called the postmodern cultural situation. There is nothing inevitable to the form that intellectual disputes have taken that accounts for their structural similarity across disciplinary lines. Rather, this unity exists because, the same issue is being contested in the various fields - the politicization of authority occasioned by the tendency of recently authoritative discourses, claiming objectivity, to become unstable and vulnerable, or, the postmodern critique of the continuity of identity has been pressed.

235. See F. Lentricchia, After the New Criticism (1980); J. Culler, ON DecoN-

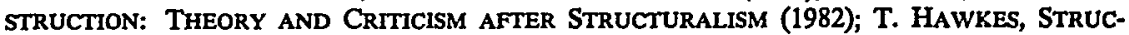
TURALISM AND SEMIOTICS (1987).

236. See, eg., E. HirSh, The AIM OF INTERPRETATION (1976).

237. D. Boorstin, The Genius of American Politics (1953).

238. See, e.g., M. Foucault, Discipline ANd Punish: THE BirTh of THE Prison (1971); M. Foucault, The History of SeXuality (1978).

239. L. Strauss, Natural Right and History (1953); A. Bloom, The Closing of the AMERICAN MIND (1987); A. GEWIRTH, REASON AND MORALITY (1978).

240. See, e.g., J. Derrida, Of Grammatology (G. Spivak trans. 1976); J. Derrida, SeLECTED SUBALTERN STUdies (R. Guha \& G. Spivak eds. 1988); E. SAID, ORIENTALISM (1978); C. LeVi-STrauss, THE RAW AND the COOKED (1970); C. GeERTZ, THE INTERPRETATION OF Cultures (1973); J. Piaget, Structuralism (1970); J. Piaget, Writing Cultures, The Poetics AND Politics of Ethinography (J. Clifford \& G. Marcus eds. 1986). 
The characteristic that movements like the New Public Law in legal scholarship, Gadamarian "hermeneutics" in the humanities, and "pragmatism" in philosophy share is that they all constitute a particular, recognizable way of situating oneself vis-a-vis the similar breakdown of traditional authoritative discourses in their respective fields. ${ }^{241}$ In one dimension, they can be understood as exemplars of ideological centrism - they seek in each manifestation to recover and reconstitute something like a reasonable center, distinct from the extremes of ideology that define the right and the left.

But the idea of centrism does not fully capture the sense of linkage we are getting at. In addition, a significant feature of this intellectual tendency is that it is situated within a particular cultural matrix where various practices - vaguely linked together as "postmodernism" have destabilized their respective disciplinary discourses. In short, the "center" chosen by the New Public Law is a distinctly postmodern center; the New Public Law is one manifestation of a new quasi-cultural social form that is associated with the appearance of postmodernism as a presence in American intellectual life. In other words, the postmodernism condition is constituted, not only by its radical avant garde - CLS in law, for example, or deconstructionism in literary criticism - but also by a particular, recognizable attempt to moderate and stabilize, to constitute a center sophisticated enough to comprehend the postmodern stance but nevertheless reformist enough to believe that it doesn't make all that much difference after all. Just as the legal process theorists constructed a center to legal thought by incorporating elements of the radical critique of the realists, while rejecting the more radical implications of realist thought, so the New Public Law is searching for a center by, in part, absorbing major elements of the radical critical legal studies approach, while attempting to avoid the more radical implications of that body of work.

This depiction of the New Public Law as a postmodern cultural form finally allows us to address what we believe ultimately distinguished the New Public Law movement - their respective positions on the map of American intellectual culture. We believe that there is a superficial liberal critique of the New Public Law that demands to know the "ground" for the normative approach that New Public Law scholars proclaim, and would reject the movement because of its failure to provide an objective, neutral basis for decisionmaking. Since we find the New Public Law's embrace of antipositivism to be a strength, rather than a weakness, we find such a critique beside the point, unless

241. Among representative scholars we would include from various disciplines are Richard Rorty, Clifford Geertz, and Hans-Georg Gadamer. 
the critic were to articulate her own neutral, objective discourse. On the other hand, the inquiry as to where the cultural norms of deliberation, tolerance, and openness are rooted does lead to the core of the left critique: the sense that when New Public Law scholars like Ackerman invoke the New Deal as a "constitutional moment," or when Michelman invokes the civil rights movement as if it represented some particular, identifiable norm, and when they speak of dialogue under ideal speech situations free from coercion and full of mutual respect, they are mistaking as a universal form of dialogue what is really the cultural motif of the largely white and relatively affluent college educated who place themselves vaguely on the progressive side of American politics. For example, there are many ways to comprehend what "the civil rights movement" meant, ranging from the social commitment to equality that New Public Law scholars emphasize, to a critical interpretation that sees in the integrationist ideology of a case like Brown the repudiation of other possibilities for African-American selfdetermination. ${ }^{242}$ The "lessons of the civil rights movement" also do not simply exist, in some objective form, available to utilize as evidence of a progressive and liberatory republican strand of American constitutionalism. In other words, it is not that the norms advocated by the New Public Law scholars are not thoroughly decent and wellintentioned. The problem is that New Public Law scholars stop short of recognizing their inevitable politically created quality, and thus tend ultimately to subdue what the left believes the project of criticism is all about. The move to moderation and stability, in short, is a move towards consensus about social norms that the left believes present political and contested issues - issues that are prematurely "accommodated" or "attended to" in the new postmodern centrism that has as its cultural form a kind of "good-guyism" or lay correlate to the reasonableness that presbyterianism represents in the religious sphere.

\section{CONCLUSION}

We have tried in this article to describe what we see as a new genre of legal scholarship, and to situate that genre in relation both to the history of legal discourse that preceded its appearance, and the other contemporary movements in law from which it is distinguished. Given our respective intellectual and political commitments, we have different ultimate evaluations of this movement. But we both agree that the New Public Law scholarship is an important intellectual re-

242. See H. Cruse, The Crisis of the Negro Intellectual (1967); Calmore, Fair Housing v. Fair Busing: The Problems with Providing Increased Housing Opportunities through Spatial decentralization, 14 Clearinghouse Rev. 7 (1980); Peller, supra note 4. 
finement of the legal process analytic on which it builds, and that the work simultaneously carries the risk of depoliticizing the aspects of radical scholarship that it incorporates. We think it appropriate to add here, however, that whatever intellectual and ideological issues separate this work from CLS, there is obviously a great deal of room for both intellectual and political alliance in specific contexts. A quick review of the actual political stances taken by well-known members of the New Public Law movement reveals that they have often been politically allied with the left, even if the left believes their scholarship might ultimately be apologetic and New Public Law scholars believe that CLS underestimates the possibilities of accommodation. Our own experience as colleagues has left us hopeful about the benefits of such alliances - and dialogue. 